MPC MAJOR RESEARCH PAPER

THE VISUAL CONSTRUCTION OF THE INDIVIDUAL EDUCATION PLAN AND PARENT INVOLVEMENT

\title{
ELIZABETH MACLAGAN
}

\author{
Dr. Ava Cross
}

The Major Research Paper is submitted

in partial fulfillment of the requirements for the degree of

Master of Professional Communication

\author{
Ryerson University \\ Toronto, Ontario, Canada
}

July 16, 2014 


\section{AUTHOR'S DECLARATION FOR ELECTRONIC SUBMISSION OF A MAJOR RESEARCH PAPER}

I hereby declare that I am the sole author of this Major Research Paper and the accompanying Research Poster. This is a true copy of the MRP and the research poster, including any required final revisions, as accepted by my examiners.

I authorize Ryerson University to lend this major research paper and/or poster to other institutions or individuals for the purpose of scholarly research.

I further authorize Ryerson University to reproduce this MRP and/or poster by photocopying or by other means, in total or in part, at the request of other institutions or individuals for the purpose of scholarly research.

I understand that my MRP and/or my MRP research poster may be made electronically available to the public. 


\begin{abstract}
In educative practices, planning documents play an important role in communicating the educational needs of students with disabilities. The Individual Education Plan (IEP) is the main document that facilitates and enables accommodation for students with special education requirements. The IEP describes a student's individual learning outcomes and services based on his or her level of educational performance (Griangreco, 1994). Research on the IEP work process has demonstrated that it can be confusing, frustrating, or ineffective in many cases (Ng, 2013). By taking the parents' perspective and experience in the creation of the IEP, one can seek to understand why this can be such a taxing communicative process. As the literature can attest, there is great emphasis on parent involvement and positive outcomes in the IEP work process. However, parent input does not appear to be of great value or importance within the IEP document. In order to address the problem of poor parent involvement in the creation of the IEP, the IEP document template must be carefully analyzed.

By taking the perspective of the parents in the IEP work process, the following research questions will be addressed:

Primary Research Question
\end{abstract}

- How do the textual and visual constructions of the IEP document elicit parent involvement in individual education planning?

When analyzing IEP documents, the visual construction and the layout can be examined in order to understand why parent involvement may be limited. 
Written language can be analyzed by semiotic theory, which studies a system of signs, including a sign, signifier, and signified (Warner, 1990). Semiotic analysis questions what constitutes representation and the use of signs and sign systems to make messages (Nuessel, 2012). Thus, using semiotic analysis can help to understand how parents perceive the IEP document in practice. By gaining a richer understanding of the IEP template, one can hypothesize how parental involvement is communicated in the IEP work process.

In considering the composition of a document, effective design enables the reader to understand information by visually grouping elements into units and indicating order through visual hierarchy (Martin, 1989). By referring to the document design and layout of a textual document, one can assess and interpret cues such as order, proximity, visual hierarchy, and visual prominence. Further, through the implementation of a semiotic content analysis of IEP templates employed across Ontario school boards, the notion of parent involvement can be better understood. 


\section{Acknowledgements}

I would like to thank Dr. Ava Cross in aiding me through the development of this Major Research Paper. Thank you also to Dr. Stella Ng and Dr. Frauke Zeller in assisting in the research process. I would also like to thank the Ryerson Professional Communication faculty for their efforts throughout the academic year. 


\section{Table of Contents}

$\begin{array}{ll}\text { Introduction } & 10\end{array}$

$\begin{array}{ll}\text { Literature Review } & 13\end{array}$

$\begin{array}{ll}\text { The IEP in Ontario } & 13\end{array}$

$\begin{array}{ll}\text { The IEP Process } & 14\end{array}$

$\begin{array}{ll}\text { Parent Involvement in the IEP } & 15\end{array}$

$\begin{array}{ll}\text { The IEP Team Meeting } & 16\end{array}$

$\begin{array}{ll}\text { Parent Knowledge and Participation } & 17\end{array}$

$\begin{array}{lr}\text { Documents in Education Planning } & 18\end{array}$

$\begin{array}{ll}\text { Document Design and the IEP } & 21\end{array}$

Semiotic Analysis and the IEP 22

$\begin{array}{ll}\text { Effective Document Design } & 25\end{array}$

$\begin{array}{ll}\text { Genre Theory and the IEP } & 26\end{array}$

$\begin{array}{ll}\text { Methodology } & 28\end{array}$

$\begin{array}{ll}\text { Method of Analysis } & 28\end{array}$

$\begin{array}{ll}\text { Data Set } & 29\end{array}$

$\begin{array}{ll}\text { Findings } & 30\end{array}$

$\begin{array}{ll}\text { Recurring Observations } & 30\end{array}$

$\begin{array}{ll}\text { Analysis } & 46\end{array}$

$\begin{array}{ll}\text { Discussion } & 52\end{array}$

$\begin{array}{ll}\text { Recommendations } & 58\end{array}$

$\begin{array}{lr}\text { Limitations and Further Study } & 60\end{array}$ 
Conclusion

References 


\section{List of Figures}

Figure 1: Visual hierarchy $\quad 32$

Figure 2: Order of elements 33

Figure 3: Student information section $\quad 34$

Figure 4: Assessment section $\quad 35$

Figure 5: Proximity of elements 36

$\begin{array}{ll}\text { Figure 6: Parent comments section } & 37\end{array}$

$\begin{array}{ll}\text { Figure 7: Parent consultation log } & 38\end{array}$

Figure 8: Parent involvement section $\quad 39$

Figure 9: Parent signature section $\quad 41$

Figure 10: Parent consultation checklist $\quad 42$

Figure 11: IEP development team 44

Figure 12: Relevant assessment data section $\quad 45$ 


\section{Appendices}

Appendix A: Raw Data Table 


\section{Introduction}

In educative practices, planning documents play an important role in communicating the educational needs of students with disabilities. The Individual Education Plan (IEP) is the main document that facilitates and enables accommodation for students with special education requirements. A special education program is defined as one that includes a plan containing specific objectives and an outline of educational services that meet the needs of the exceptional individual (Ministry of Education, 2004). The IEP describes a student's individual learning outcomes and services based on his or her level of educational performance (Griangreco, 1994). Research on the IEP work process has demonstrated that in many cases it can be confusing, frustrating, or ineffective in many cases $(\mathrm{Ng}, 2013)$. By taking the parents' perspective and experience in the creation of the IEP, one can understand why this can be such a taxing communicative process. As the literature attests, there is great emphasis on parent involvement and positive outcomes in the IEP work process. However, the IEP document does not show parent input to be of great value or importance. In order to address the problem of poor parent involvement in the creation of the IEP, the IEP document template must be carefully analyzed. 
By taking the perspective of the parents in the IEP work process, the following research questions will be addressed:

Primary Research Question

- How do the textual and visual constructions of the IEP document prompt parent involvement in individual education planning?

Secondary Research Questions

- How do the roles of text and genre communicate the notion of parent involvement in individual education planning?

- How does the IEP template either increase or decrease the opportunity for parent involvement?

- How does the IEP template visually communicate the importance of parent involvement?

- Referring to semiotic analysis, does the visual construction of the IEP invite parent participation?

When analyzing IEP documents, the visual construction and the layout can be examined in order to understand why parent involvement may be limited. Written language can be analyzed by semiotic theory, which studies a system of signs, including a sign, signifier, and signified (Warner, 1990). Semiotic analysis questions what constitutes representation and the use of signs and sign systems to make messages (Nuessel, 2012). Thus, using semiotic analysis can help to understand how parents perceive the IEP 
document in practice. By gaining a richer understanding of the IEP template, one can hypothesize how parental involvement is communicated in the IEP work process.

In considering the composition of a document, effective design enables the reader to understand information by visually grouping elements into units and indicating order through visual hierarchy (Martin, 1989). By referring to the design and layout of a textual document, one can assess and interpret cues such as order, proximity, visual hierarchy, and visual prominence. Further, through the implementation of a semiotic content analysis of IEP templates employed across Ontario school boards, the notion of parent involvement can be better understood. 


\section{Literature Review}

\section{The IEP in Ontario}

Within North America, the creation of the IEP for an exceptional pupil is a mandated process, typically governed through provincial or state legislation. In Ontario specifically, the Ministry of Education published the document, Individual Education Plans: Standards for Development, Program Planning, and Implementation, in order to improve the consistency and the quality of the specialized education program (Ministry of Education, 2004). The Ministry guidelines provide both specific criteria that must be documented in the IEP and a suggested format for the IEP document. In September 2002, the Ministry provided school boards with an IEP template and encouraged the revision of existing IEP forms to capture the information presented in the template (Ministry of Ontario, 2004). Since the format of the IEP document is not government regulated, each school board can create a unique IEP template.

In examining the document requirements of the IEP in Ontario, the Ministry of Education requires distinct elements to be included. The IEP must include the following information: specific educational expectations for the pupil, an outline of the special education program and services, a statement of the methods by which progress will be reviewed, and a postsecondary transition plan for pupils 14 years of age or older (Ministry of Education, 2004). In the process of developing the IEP, parents are invited by school staff in order to attend and collaborate in the IEP meeting. The IEP meeting poses a prime opportunity for both professionals and parents to discuss the development of the IEP. Since the IEP process is the one mandated interaction between schools and 
parents, it must reflect to the fullest degree the potential for strong collaborative relationships whereby parents are equal partners (Pruitt, Wandry, \& Hollums, 1998). The Ontario standard for consultation with the student, parents, school staff, and external resources is a valuable source of information in the development and the implementation of an IEP (Gallagher, 1995).

\section{The IEP Process}

As set forth by the Ministry of Education, the IEP process consists of five suggested phases. The five phases are defined as:

1. Gather information.

2. Set the direction.

3. Develop the IEP as it relates to the student's special education program and services.

\section{Implement the IEP.}

5. Review and update the IEP (Ministry of Education, 2004).

When preparing and developing the IEP document, input is required from several information sources. Health-related, school-based support for children with special needs requires the integrated work of families, health care professionals, and educators $(\mathrm{Ng}$, 2013). In theory, the IEP meeting acts as a valuable opportunity for all contributors to collaborate cohesively in order to generate the best plan for the given pupil. Integrated working is defined as coherent and coordinated service delivery to individual users across a broad range of service providers (Mur-Veeman \& Van Raak, 2008). The literature examining the work process of the IEP shows that the input of parents is often 
marginalized or disregarded. Many research studies seek to examine how parents define ideal participation in the work process, what constitutes parent satisfaction with participation, and how parents and professionals can develop and maintain good communication and relationships (Salembier, 1997). The communication practices and opportunities between professionals and parents in the creation of the IEP are of concern and interest.

\section{Parent Involvement in the IEP}

The parent involvement aspect of the IEP work process is strategically designed to modify the power relationship between parents and professionals to a more equitable level (Gallagher, 1995). However, the level of parent involvement in developing the IEP document varies substantially. Some professionals maintain the view that parents do not have the necessary information or expertise in decision making for constructive contributions to the IEP (Gilliam \& Coleman, 1981). A growing body of literature emphasizes the positive impact of parent involvement in their children's success in school, meanwhile proposing strategies to promote and facilitate collaboration between families and education professionals (Jung, 2011). The literature suggests various open communication practices that may help to foster family involvement; however, the format of the IEP document itself is not considered in the achievement of effective communication.

The recurring theme of imbalance in parental contributions in the IEP development is of concern while educators seek to construct the best possible education plan. Parents, teachers, and health care professionals have all expressed concerns that despite all of the 
work that goes into the IEP process, their knowledge is not recognized or utilized effectively and efficiently $(\mathrm{Ng}, 2013)$. By taking the parents' perspective in the development of the IEP, the barriers that prevent effective communication can be assessed and analyzed. Taking the standpoint of the family can provide critical information to inform and to improve health care professionals' practice at the health care education junction ( $\mathrm{Ng}, 2013)$. More specifically, examining the IEP document template can provide information on why the communication process is less effective in practice than it is in theory. Research suggests that although parents may attend and participate in IEP meetings, few parents are directly involved in developing objectives, shaping educational programs, or deciding on assessment procedures (Lynch \& Stein, 1982).

\section{The IEP Team Meeting}

The IEP meeting is the prime opportunity for parents to voice their opinions, concerns, and suggestions in the development of the IEP document. Some researchers argue that during the IEP team meeting meaningful participation continues to be more the exception than the rule (Heatherington et al., 2010). Research shows that increased parental participation, parent education on special education law, and proper adherence to IEP protocol are common measures that educators should take to improve IEP meetings (Fish, 2008). One of the main goals of the IEP meeting is to communicate and collaborate effectively in order to develop objectives and goals for the student in the IEP document. However, many parents express that IEP objectives are often determined by team members prior to the meeting, leaving parents' suggestions disregarded (Fish, 2008). 
Although parents attend their child's IEP meeting, they often have no involvement in developing objectives, interventions, or methods of evaluation (Spann, 2008). In a study conducted by Vaughn in 1988, themes emerged of parents feeling uninvolved in the IEP work process, few could identify specific contributions, and little effort was made to evaluate parents' roles and their knowledge and perceptions of their child (Vaughn, 1988). Common findings in the literature suggest that the IEP document is often filled out prior to the IEP team meeting. With time as a predominant concern, school personnel may preplan an IEP meeting and present the IEP plan to the parents whereby parents must react to the recommendations (Weishaar, 2010).

\section{Parent Knowledge and Participation}

Although theoretically the knowledge of parents is viewed as highly valuable in the IEP document creation process, this is not always the case in practice. The knowledge that parents have of their own child is devalued, their concerns are dismissed, and their reports of the child's behaviour are distrusted (Gallagher, 1995). The thematic recurrence in the literature of devalued parent knowledge begs the question to how the IEP document itself may obstruct parent involvement. In spite of theoretical validation and legal mandates in special education for parent participation, many studies have indicated that parent roles in the IEP process are not noticeable or influential, and that parents are not treated as equal partners in the work process (Spann, Kohler, \& Soenksen, 2003).

Much of the literature discusses and analyzes the recurring theme of devalued parent participation in the IEP work process. Studies have found that the bureaucratic processes that schools utilize contribute to the lack of parent participation, including 
medical and deficit discourse, professional discourse and jargon, policy interpretations, and meeting practices (Bacon \& Causton-Theoharis, 2013). The concept of team culture is notable in playing a large role in the lack of parent participation in the IEP work process. Team culture, defined as the attitudes and beliefs that are valued by collaborating professionals, may impact parent participation in the way the team structures the meeting environment, the discourse team members use, or the varying degrees of respect (Dabrowski, 2004). The power struggle faced by parents in the process of developing the IEP is common. The knowledge offered by parents is often considered subjective and unworthy of expert consideration by the IEP team (Bacon \& CaustonTheoharis, 2013). This recurring theme of devalued parent participation leads to question if the format and construction of the IEP document may be limiting parent involvement and effective communication. According to the IEP Standards, parents provide information about the child's personality, development, and learning, but this does not necessarily lead to shared decision making or having a meaningful voice in the education process (Underwood, 2010).

\section{Documents in Education Planning}

When considering the process of education planning, the role of documents is critical. Within the education planning process, documentation is used to identify, plan, and review a student's progress. In early childhood education, the Reggio education theory combines various forms of textual documents in education planning to make learning progress visible (Berdoussis, Guyevskey, \& Wien, 2011). Pedagogical documentation provides the teacher's story of the child's understanding, allowing for 
collaborative discussion and interpretation to generate ideas for further learning (Berdoussis, Guyevskey, \& Wien, 2011). Graphic design principles and visual literacy are important to pedagogical documentation in order to communicate clearly (Berdoussis, Guyevskey, \& Wien, 2011). Similar to early childhood education, the special education system uses distinct documents, including the IEP, during the education planning process (Steere \& DiPipi-Hoy, 2013). As one can note, the role of documents in education planning is critical in order to chronicle students' progress and needs. In order to use documents effectively, educators require training in successfully completing planning documents to address a student's annual goals (Landmark \& Zhang, 2012). Through documentation, educators are able to track the progress of students that may otherwise not be visible or traceable. Information provided by documents can serve as qualitative support for the effectiveness of educational planning (Chabotar \& Montgomery, 1975).

Within special education and the IEP work process, the IEP team meeting is the ideal opportunity for parents to contribute to a child's education plan. Correlational research has clearly linked parent involvement with a number of student outcomes, including improved grades, attitudes towards school, self-concept and behaviour, increased completion of homework, higher attendance rates, and lower suspension rates (Gerstein, 2004). As one can recognize, the importance of parent involvement is high due to the strong connection between parents' contributions and a child's educational outcomes. Active parent participation in the IEP development process has been associated with parents' greater satisfaction with programming and placement decisions, positive feelings towards the parent-professional partnership, and more confidence in 
teachers' professional abilities (Abrahamson, Wilson, Yoshida, \& Haggerty, 1983). With this in mind, it is evident that the positive outcomes of parent participation in special education planning are increased when the opportunity is presented. When professionals recognize family expertise, families are supported, their functioning is enhanced, and family strengths begin to emerge (Van Haren \& Fiedler, 2008).

In addition to their right to contribute to the IEP development, parents also provide critical information about the child that educators may not be aware of when developing a comprehensive IEP (Cannon, 2011). Due to the high level of involvement that they hold in their child's routine functions, parents provide a distinct perspective, different from that of a healthcare professional or an education professional. A parent's involvement in the entire process can significantly influence the type and the level of educational services that the student receives (Cannon, 2011). By gaining the input and expertise of the parent in the IEP development process, the education professional is more likely to receive the most accurate and complete understanding of the child's needs.

Since the IEP process is the single mandated interaction between schools and families, it must reflect to the fullest degree the potential for strong collaborative relationships (Pruitt, Wandry, \& Hollums, 1998). During the IEP work process, the IEP template is referred to in order to extract the necessary information for the development of the IEP. In this activity, parents want to perceive themselves as equal partners in a team striving for the same goals (Pruitt, Wandry, \& Hollums, 1998). Since the IEP team meeting focuses on filling out the IEP template, the role of the parents may be largely defined by the construction of the template used. Unless their message is recognized, 
internalized, and acted upon, true collaboration based on the total picture of the child and the family cannot be realized (Pruitt, Wandry, \& Hollums, 1998). Thus, the input of parents in the creation of the IEP must be documented within the IEP template.

The literature discusses and identifies reasons for poor communication and parent input in the IEP development. More specifically, the literature does not analyze or assess the linguistic or visual construction of the IEP document. Within Ontario, there is no mandatory document template for the IEP, causing variation in the document. Within IEP templates, textual fields are positioned for completion by educators and staff members, therefore excluding the parents. In addition, the IEP template in the Ministry of Education Guidelines has a section stating that the IEP was developed by a staff and does not list the parents as contributors (Ontario Coalition for Inclusive Education, 2004).

\section{Document Design and the IEP}

The literature discusses the poor communicative practices in developing the IEP, but it does not address the IEP document format. Thus, by examining the IEP document, the problem of low parent involvement can be addressed. The consideration of form changes in the IEP should be driven by an improved conceptualization of their primary purpose and how they can be revised to fulfill their intended purpose for all educational team members (Giangreco, 1994). By focusing on increasing parent participation in the IEP team meeting, the IEP template designer can consider parent positioned elements. In addition, reorganizing or reformatting the IEP document may enable more effective communication practices (Giangreco, 1994). 
Document analysis can be helpful in understanding the limitations of a work process. Contemporary documents use multimodal forms to express ideas, arguments, and narratives, acting as a field of research (Prior, 2010). By analyzing the IEP document, the work process of the IEP team meeting and parent involvement can be better understood. In addition to textual features within a document, non-textual elements add to their complexity in the context of socially organized projects seeking to meet key objectives (Prior, 2010). The analysis of both the textual and visual construction of IEP templates can help to understand why parent involvement may be limited. In the document analysis process, one must consider the dynamic involved in the relationships between production, consumption, and content of the IEP documents (Prior, 2010). The elements of visual form, content, and presentational form must be considered when strategically analyzing a document (Rose, 2012). Therefore, the IEP document can serve as an analytical tool in understanding how parent involvement is limited in the IEP work process.

The IEP document, acting as a genre, can be analyzed through the application of semiotics. Written language can be analyzed by semiotic theory, which studies a system of signs, including a sign, signifier, and signified (Warner, 1990). By applying semiotic theory to the IEP document, one can seek to understand how the IEP is perceived and used in practice. The signs found within the IEP document may help to answer how parent participation in the IEP work process can be improved. 


\section{Semiotic Analysis and the IEP}

The theoretical models created by Ferdinand de Saussure and Charles Sanders Peirce stand as frameworks for semiotic analysis (Nuessel, 2012). Semiotic analysis questions what constitutes representation and the use of signs and sign systems to make messages (Nuessel, 2012). Thus, using semiotic analysis can help to understand how parents perceive the IEP document in practice. Semiotic research has identified four basic types of forms: signs, texts, codes, and figural assemblages (Nuessel, 2012). Referring to the IEP document, both signs and text are of interest in how codes are interpreted. Within a document, the text signifies many means of communication and interpretation (Rastier, 2012). With this in mind, the semiotic analysis of the IEP template can help aid understanding of parental involvement in the IEP work process. In the semiotic reading of a text, it is essential to outline how the text represents the phenomenon under study as states and processes of reality (Torronen, 2002).

Semiotic analysis has been applied to various visual phenomena. Semiotics represents approaches to analyses of texts, including written texts and the texts afforded by other observables (Nöth, 1995). In Roland Barthes' essay entitled, “The Photographic Message," Barthes describes the photographic image as a message without a code, composed of a connoted message and a denoted message. Barthes describes the denoted message as the analogue itself, and a connoted message as the way in which the society communicates what it thinks (Barthes, 1977). Similar to the analysis of photographs, the same concepts of both connotation and denotation can be applied to textual documents. 
In his analysis of Sarrasine, a novella by Honoré de Balzac, Barthes divided the text into numbered, arbitrary segments called lexias, containing a few words to several sentences (Gilgun, 1999). This approach allows for the analysis of language found within textual documents. When reading a text, the reader observes infinite meanings whose dimensions are based on the words of the texts (Gilgun, 1999). When examining the IEP template, both visual cues and linguistic cues can demonstrate the notion of parent involvement within the document. With this in mind, the semiotic analysis of a text is a step-by-step process, in which a text is gradually analyzed, decomposed, and segmented (Gilgun, 1999).

The way in which a text is perceived heavily relies upon the knowledge of the individual reader. For example, while reading the IEP template, a parent may misunderstand information if medical jargon is frequently used. The number of potential connotative readings is based on individual differences in practical, national, cultural, and aesthetic knowledge (O’Donohoe, 1997). In visual documents, the elements presented are methodically selected in order to achieve the desired connotative meaning (Pateman, 1980). This same rule can be applied when analyzing texts as part of a work process because the document in use may guide the meeting discussion.

Both the visual construction and the discourse found within the text are tailored to achieve a desired interpretation and work process function. Semiotic analysis has the advantage of enabling a richer understanding of texts by focusing on the objective formal relationships (Bell \& Milic, 2002). By gaining a richer understanding of the IEP template, one can hypothesize how parental involvement is communicated in the IEP documents. 
In addition to the analysis of language using a semiotic approach, literature suggests that visual research can play a key role in improving policy. A visual analysis approach promises to provide educational research with a strategic method to help transform the boundaries between theory and practice (Nguyen, 2012). Examining the visual construction of the IEP template can also help to determine signs and signifiers within the textual document. Visual methodologies enable the questioning of the theoretical implications of texts and discourse that are constructed behind a policy framework (Nguyen, 2012). By applying a visual analysis approach to IEP documents, one can understand how the need for parental contributions is communicated visually.

Visual rhetoric is the effective use of visual elements for communicating information (Rosenquist, 2012). Visual cues found within each IEP template can communicate great meaning when perceived by the reader. The communicative purpose of a document can be analyzed according to four elements: the intended communicative effect, the document topic, the target group of the document, and the organizational goal as a social result (Lentz \& Henk, 2004). With this in mind, the IEP template can be analyzed according to how parents perceive visual cues within the document when participating in the IEP work process.

\section{Effective Document Design}

Effective document design enables the reader by visually grouping information into units and indicating order through visual hierarchy (Martin, 1989). For example, by referring to the design and layout of a textual document, one can assess and interpret cues such as order, visual hierarchy, and visual prominence. When designing visual forms, 
primary information is displayed as a prominent feature, whereas supplemental information is more subdued in visual presence (Horton, 1990). Further, page-formatting techniques are extremely effective in communicating the structural hierarchy of a document. According to the Gestalt principle of proximity, the strength of the relationship of visual elements is directly proportional to the distance separating the items (Gribbons, 1991). By referring to the Gestalt principle of proximity, one can understand how specific elements within a document may be perceived as unrelated due to a lack of proximity on the typeset page.

\section{Genre Theory and the IEP}

When performing a semiotic analysis of the IEP document, the language used within the template can be strategically analyzed. By examining the language present within the IEP templates (see Appendix A), one can understand how parental input may be controlled by the document construction itself. In order to understand the language identified through semiotic analysis, genre theory can be used in the analysis and interpretation of the template. Genre theory considers the intended communicative purpose, form, and content of a document (Kwasnik \& Crowston, 2005). The study of genre recognizes how the delivery, context, and rhetorical structure of a document play complementary roles in information transfer (Kwasnik \& Crowston, 2005). Thus, genre theory can be applied to the IEP template in seeking to understand how parental involvement can be improved upon.

In the analytical process, it is necessary to consider the context of use as well as the technical details of the documents (Kwasnik \& Crowston, 2005). By considering the 
nature of the IEP meeting and the IEP team, one can better understand how the structure of the IEP document can enable or prevent collaboration. Within discourse, relational bonds are formed in which creation, transformation, and structure are maintained (Barrett, Thomas, \& Hocevar, 1995). With these bonds in mind, genre theory allows for the analysis of hierarchical power structures in terms of the IEP team. The nature of genre in defining communicative roles is important when considering the ways in which professions compete for power through the use of genre (Popham, 2005). Thus, one can understand how the contributions of parents in the IEP development process may be limited by the structure of the IEP.

As the literature can attest, there is great emphasis on parent involvement and positive outcomes in the IEP work process. However, the IEP template does not display the importance of parent input. In order to address the problem of poor parent involvement in the creation of the IEP, the IEP document template must be carefully analyzed. By understanding how the IEP template is designed and constructed, the communicative practices during the IEP meeting can be better understood.

Recommendations for a standardized IEP template will be made in order to suggest solutions the problem of low parent involvement in the IEP process 


\section{Methodology}

\section{Method of Analysis}

In order to address the research questions, the methodology employs a semiotic content analysis, including both textual analysis and visual analysis. The tools of semiotic theory were used to code and analyze the language within each IEP template. As described in semiotic theory, the text will act as the sign, leading to the signified or linguistic meaning of specific words and phrases. By coding identified words and phrases, themes will begin to emerge that will help to understand how parent involvement is communicated in the IEP. For example, the use of the word "consultation" (an external party) evokes different meaning than the word "involvement" (an internal party). By examining the language used within each IEP, the notion of parent involvement can be better understood through how the language is used to define the level of contributions parents can make.

To address the concern of the visual construction of the IEP, document design theory was applied in order to understand how the visual elements of the IEP may influence parent involvement. Elements requiring completion by the parent were coded, counted, and analyzed in order to understand the role of the parent as visually represented in the IEP templates. Document design theories, including order, visual hierarchy, proximity, and prominence, were used in order to understand the communicative effect of the document. For example, the concepts of hierarchy and order were used to assess the prominence of parental involvement conveyed in each IEP template. 
To begin the analysis process, a hard copy of each IEP was examined. Each template allowed for the examination of both textual elements and visual elements. In the initial stages, the primary goal was to identify overarching themes within each IEP. Excel was used in order to conduct both the textual analysis and the visual analysis of each IEP template in identifying recurring themes. The data set was analyzed and coded according to the contents of each template. From here, Excel allowed for both qualitative and quantitative analysis of emerging self-defined themes. The identification of the most predominant themes and codes across the entire data set was recorded and interpreted according to semiotic theories and document design theories. Numerical figures allowed for the presentation of the frequency of specific themes and codes found within the data set.

\section{Data Set}

The data set gathered for this investigation consists of IEP templates used by Ontario public school boards. Each school board employs a unique IEP template that allowed for the analysis of variations found in the documents' format. By restricting the data set to public school boards within Ontario, this will allow for the careful analysis of IEP documents that follow the Ontario Ministry of Education IEP Guidelines. Thirtyseven IEP templates were located for the investigation by accessing each Ontario public school board's website. Each of the templates was examined by applying the method of analysis. 


\section{Findings}

Through conducting the semiotic content analysis of the IEP templates several key findings emerged. The data gathered is displayed in Appendix A of the report, providing a complete listing of the data collected. The findings help to illustrate the construction of the IEP templates and the major recurring observations.

\section{Recurring Observations}

When analyzing the IEP templates several recurring observations involving the employment of document design principles emerged within the data set. The frequent occurrence of the following observations posed as prime opportunities for further analysis:

- Document format

- Visual hierarchy

- Order

- Proximity

- Prominence

- Parent fields

The above categories of observation have been investigated below. 


\section{Document Format}

The data set shows great variation across the templates. In Ontario there is no standard format for the IEP template, therefore creating the opportunity for customization of the IEP for each school board. The Ministry of Education provides mandatory elements that must be contained in the IEP, but the overall structure is open to adjustment. Due to the lack of standardization of the IEP document, there is no guarantee that each school board's template will present the same information. As the data set in Appendix A shows, there is variation in the format of each IEP template. The minimal number of elements requiring parent completion in the templates may risk lower parent involvement. The variation found across the individual IEP templates is most notable in terms of the layout, typeface selection, element size, element order, and the inclusion of key IEP elements.

\section{Visual Hierarchy}

The purpose of visual hierarchy is to visually separate items in order to achieve hierarchy within a visual document. Within the IEP document, visual hierarchy is realized through the use of headings, bold typefaces, and the relative size of distinct elements. The majority of the IEP templates effectively employ visual hierarchy to separate individual elements. The use of bold typefaces allows for the identification of primary sections within the IEP. Headings act as a guide to lead the reader through the document in identifying primary information in the IEP. 
The use of visual hierarchy is effective in the majority of the IEP templates in identifying major sections. As shown by the Appendix A data set, there is no section solely positioned for completion by parents. The visual hierarchy of elements correlates to the order in which the IEP sections appear. As displayed in the following diagram, visual hierarchy can be achieved through the application of varying font sizes, bold typefaces, and the relative size of the red circles. In effect, these strategies can be used in order to focus the reader's attention toward a particular area when viewing a document. In Figure 1, the difference between bold, regular, and italic typefaces can impact the viewing of a document. In addition, the size of textual elements can be strategically used in order to capture the viewer's attention. A textual element with a large, bold font will communicate increased importance on the typeset page.

\section{BOLD REGULAR ITALIC HEADINGS \\ C1 FONT SIZE FONT SIZE FONT SIZE \\ FONT SIZE}
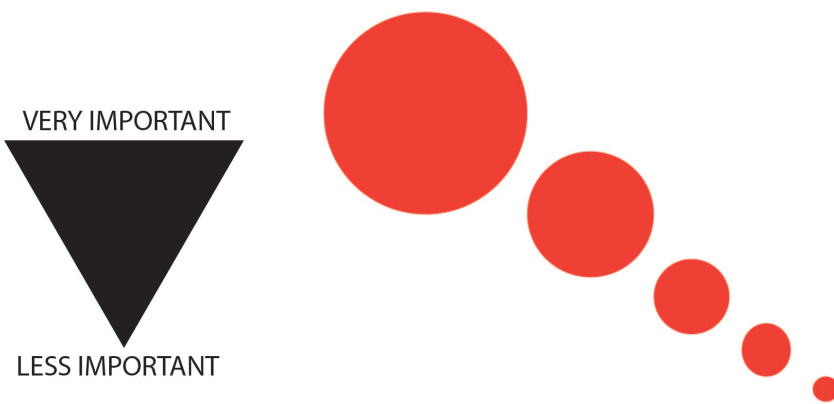

Figure 1: Visual hierarchy 


\section{Order}

The order of key IEP elements in the data set was recorded by referring to heading titles. The order of sections and elements contained within the IEP plays an important role in the notion of parent involvement in the IEP development process. The order of elements contained within the IEP template can be described as the sequence in which they appear throughout the document. In document design, it is common practice for the most important elements to be presented first, and the least important elements to be presented last.

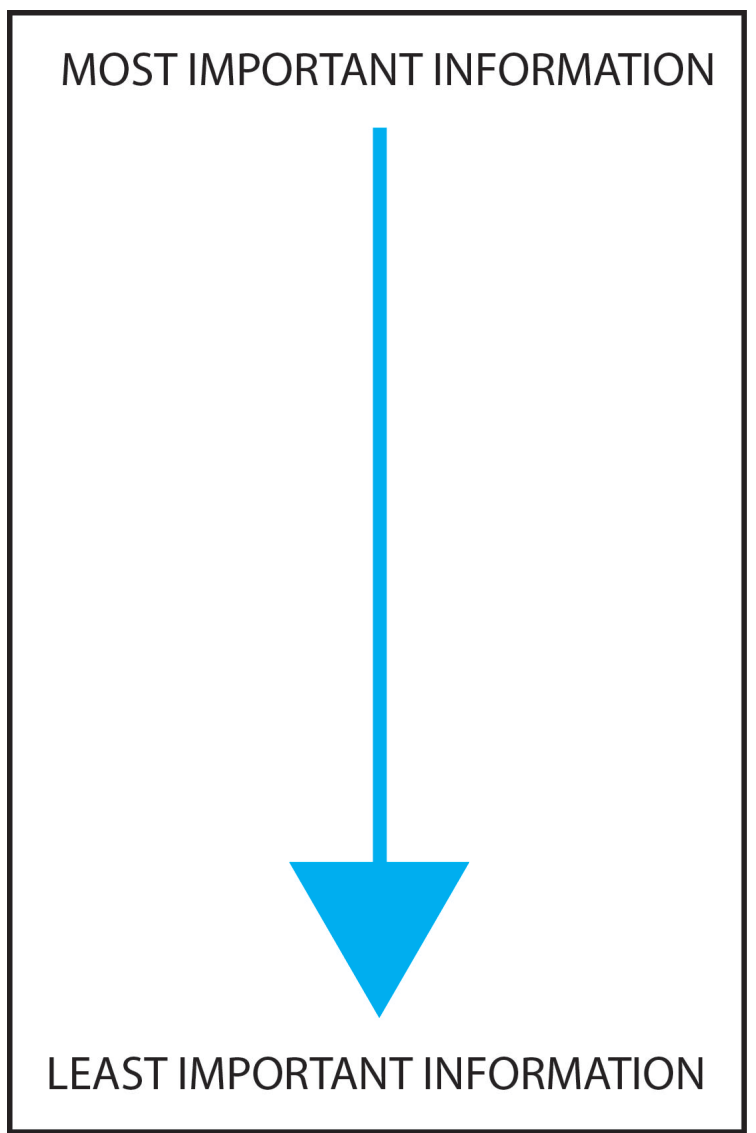

Figure 2: Order of elements 
Figure 2 demonstrates the placement of the most important information at the top of the typeset page followed by least important information at the bottom of the page. With this in mind, order has the potential to visually communicate the importance of the parent's input in completing textual fields within the IEP. Within the data set, there are recurring trends in terms of the order of distinct IEP sections. 25 of the 37 IEPs present the "Student Information" section first on the typeset page. The "Student Information" section presents key material pertaining to the student under assessment, as visible in Figure 3.

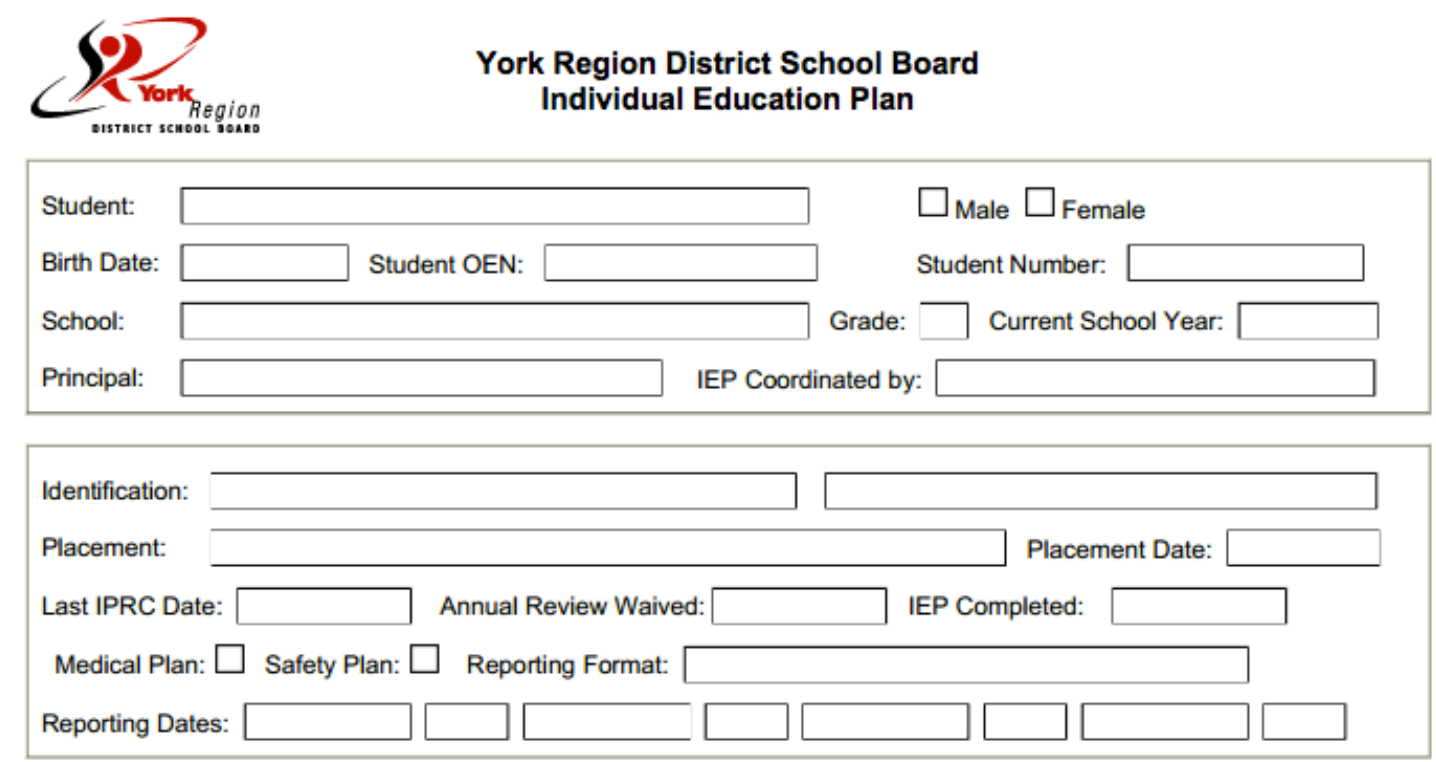

\section{Figure 3: Student information section}

As presented in Figure 3, the "Student Information" section seeks key information pertaining to the student's identification for a special education plan. 
Following the "Student Information" section, the "Assessment" section is presented whereby clinical assessments are documented as demonstrated in Figure 4.

\begin{tabular}{|c|c|c|}
\hline \multicolumn{2}{|l|}{ Relevant Assessment Data: } \\
\hline Date & \multicolumn{1}{|c|}{ Information Source } & Summary of Results/Diagnosis \\
\hline & & \\
\hline & & \\
\hline & & \\
\hline & & \\
\hline
\end{tabular}

\section{Figure 4: Assessment section}

The "Assessment" section is followed by the following sections:

- Strengths, Needs, and Accommodations

- IEP Education Plan

- Summary of Information Sources

- Evaluation and Reporting

- Log of Parent/Student Consultation

- $\quad$ Parent Comments

The "Parent Comments" section typically falls within the last pages of the IEP, causing it to appear last in the order of document elements. The perception of this key section appearing both last in the IEP and after the "IEP Education Plan" causes one to question the value of parent participation. When addressing the concept of order, the placement of elements holds a close relationship to the concept of proximity whereby the order in which elements appear can impact the perceived relationship. 


\section{Proximity}

The proximity of elements impacts the degree of the relationship between them as perceived by the user as demonstrated in Figure 5 .
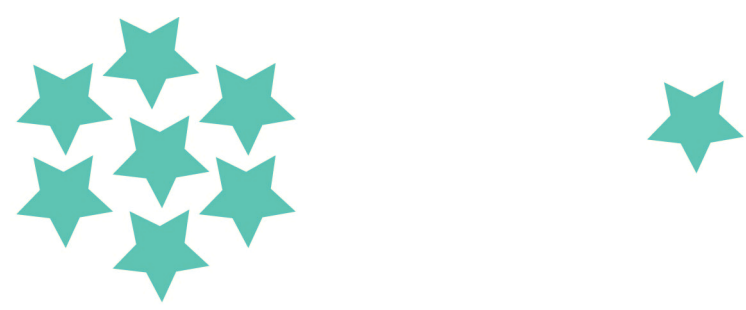

RELATED ELEMENTS

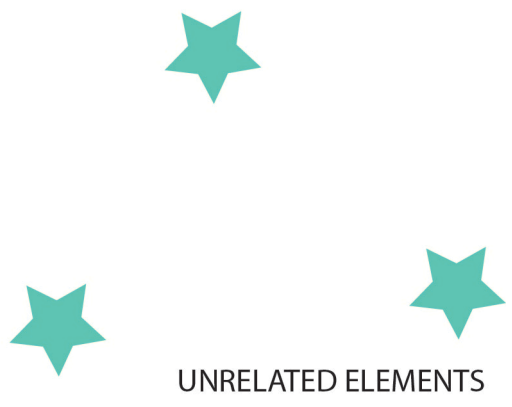

\section{Figure 5: Proximity of elements}

The degree of proximity of the parent positioned sections to key IEP elements impacts their perceived relationship. According to the Gestalt principle of proximity, the strength of the relationship of visual elements is directly proportional to the distance separating the items (Gribbons, 1991). By applying the Gestalt principle, one can understand how elements within the IEP may be perceived as unrelated due to substantial distance separating the items. Elements positioned for parent completion, including the "Parent Comments" section, lack proximity to the "IEP Education Plan" section. The majority of templates that include a "Parent Comments" section present this area several pages after 
the "IEP Education Plan." Since the "Parent Comments" section is placed after the "IEP Education Plan", one may perceive these elements as unrelated. In addition, the "IEP Education Plan" may be completed prior to the input of the parent since it appears before the "Parent Comments" section.

\section{Prominence of the Parent}

The prominence of the word "parent" in the IEP templates is low, as demonstrated by the headings employed in each document (see Appendix A). The low prominence of parent input within the IEP is evident in several ways. First, there are few textual elements labeled "parent" within each template. Second, there is minimal visual emphasis of the word "parent" through the implementation of headings or bold typefaces. Headings are employed in the IEP to indicate the hierarchy of elements and aide the viewer in identifying key sections. 21 of the 37 templates contain the "Parent Comments" section, 26 templates contain the "Parent Signature" section, and 23 templates contain the "Parent Consultation" section. The fields positioned for parent completion are typically within the section labeled "Consultation and Planning". Throughout the entire data set, there is no section positioned solely for the parent's completion. As visible in Figure 6, the "Parent Comments" field, placed under the "Consultation" heading, is the only area for the parent's input. 
Individual Education Plan

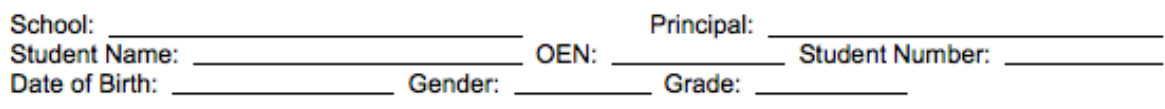

The Principal has the legal requirement to implement and monitor the IEP.

The Plan has been developed according to the Ministry's standards, addresses the student's strengths and needs, and the learning expectations will be reviewed and student progress monitored at least once every reporting period.

Principal's Signature

Date

$\square$ We have received a copy of the IEP

$\square$ We were consulted in the development of the IEP

$\square$ We have declined the opportunity to be consulted

Parent(s)/Guardian/Student Comments:

Parent/Guardian Signature

Date

\section{Figure 6: Parent comments sections}

Aside from the "Parent Comments" section, the parent's role in the IEP document lacks visual prominence.

\section{Parent Fields}

When creating the IEP, fields requiring completion by parents provide the opportunity for parent involvement. The parent fields found within the data set include the "Parent Comments" section, "Parent Signature" section, and "Parent Consultation Checklist". Typically, these areas are placed under a heading labeled "Parent 
Consultation". However, the data set shows that, only a few of the IEP templates contain the "Parent Comments" section, "Parent Signature" section, and "Parent Consultation Checklist (see Appendix A). Although an IEP template may contain these fields, because their overall presence is minimal there is only marginal opportunity for guaranteed parent completion of textual fields. Figure 7 shows the common formatting of the "Parent Consultation" section of the IEP.

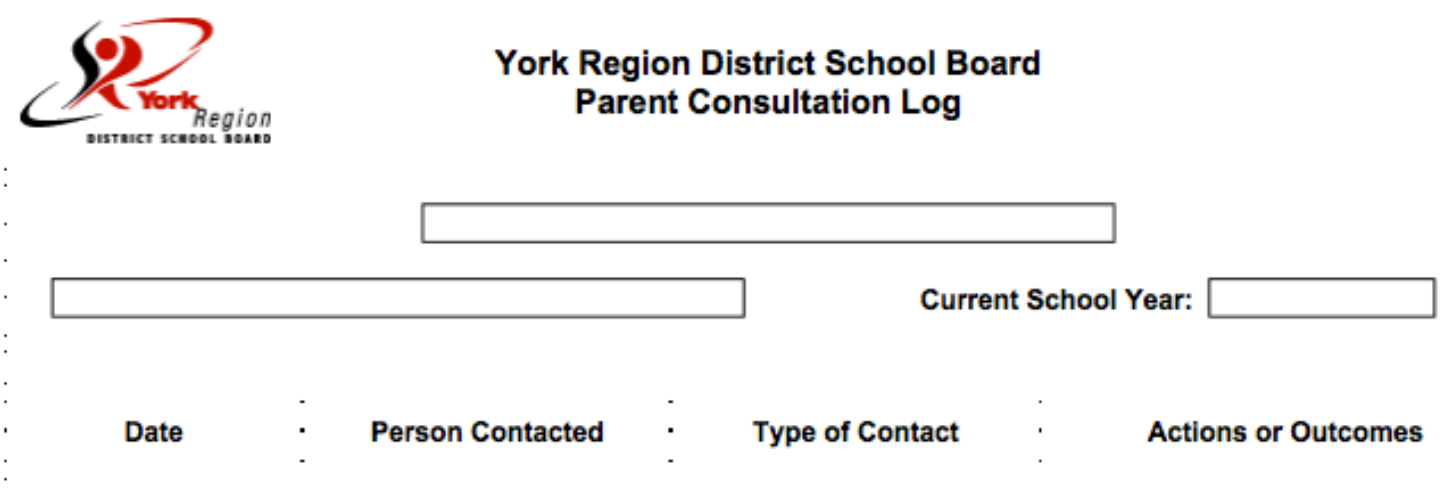

\section{Figure 7: Parent consultation log}

\section{Parent Comments Section}

Within the IEP, one of the prime opportunities for parent contribution is a section labeled "Parent Comments". In this section, the parent is provided with the opportunity to document their concerns and the needs of their child as visible in Figure 8. Without this section, the parent has no designated area to provide his or her concerns. In addressing the "Parent Comments" section, there are several interesting elements to analyze, including but not limited to: the section's presence, the field size, the proximity of the section to other elements, and the section's order. In many of the IEP templates, the 
"Parent Comments" section is the only area for parents to provide feedback and directly contribute to the IEP. Most commonly, the "Parent Comments" section is located at the end of the IEP. Across the IEP templates in the data set, the size of the textual field varies tremendously. The majority of the IEPs provide little space for this section, leaving minimal opportunity for parents to state all of their concerns and needs. The field is not within close proximity to important IEP areas, including the "IEP Education Plan". Since several pages fall between the "Parent Comments" field and the "IEP Education Plan", one may perceive these elements as unrelated due to low proximity. In addition, the "Parent Comments" section appears at the end of the IEP template, causing it to appear as a lower priority when completing the IEP.

\section{Parent/Guardian/Student Involvement}

I I was consulted in the development of this IEP

I declined the opportunity to be consulted in the development of this IEP

I have received a copy of this IEP

Parent/Guardian/Student Comments:

Parent/Guardian Signature: Date:

\section{Figure 8: Parent involvement section}

\section{$\underline{\text { Parent Signature }}$}

The "Parent Signature" section requires the parent(s) of the child to approve the IEP's contents. The presence of the "Parent Signature" section, as presented in Figure 9, is important in order to ensure the parent has reviewed their child's IEP. 
$\square$ We have received a copy of the IEP

$\square$ We were consulted in the development of the IEP

$\square$ We have declined the opportunity to be consulted

Parent(s)/Guardian/Student Comments:

Parent/Guardian Signature

Date

\section{Figure 9: Parent signature section}

As presented in Figure 9, the "Parent Signature" section commonly falls after the "Parent Consultation Checklist" and "Parent Comments" sections. The placement of all three elements occurs after the "IEP Education Plan". However, within the data set, 11 of the 37 IEP templates do not contain a "Parent Signature" section. This is concerning because the parent should be provided with the opportunity to approve the IEP's contents. In addition, if the parent is meant to be an equal partner in the IEP process, they should be presented with the opportunity to evaluate the IEP. In the data set, the majority of the IEP's place the "Parent Signature" section at the end of the document, which allows the parent to approve the IEP.

\section{Parent Consultation Checklist}

The "Parent Consultation Checklist" acts as a verification tool to assess the parent's level of involvement in the IEP development process. The checklist typically includes the following options: 
* I was consulted in the development of this IEP.

* I declined the opportunity to be consulted.

* I have received a copy of this IEP.

Any comments I provided are noted above.

Figure X presents a "Parent Consultation Checklist" with commonly occurring predefined descriptions for the parent to select:

\section{Parent/Guardian/Student Involvement}

I was consulted in the development of this IEP

I declined the opportunity to be consulted in the development of this IEP

$\bigcirc$ I have received a copy of this IEP

\section{Figure 10: Parent consultation checklist}

Thirteen of the 37 IEP templates in the data set do not contain the "Parent Consultation Checklist" section. The absence of this section may cause one to believe that the parent's involvement in the IEP development process is not a concern.

\section{Language Use}

The language used in the IEP templates may function in defining the role of the parent in the IEP development process. There is heavy use of the word "consulted." The word "consulted" is used within the "Parent Consultation Checklist" that appears at the end of the IEP as demonstrated in Figure 10. The use of this word causes the parent to be perceived as an external information source that is separate from the IEP development team. The word "consultation" is commonly defined as to ask the advice or opinion of someone in order to make a decision (Merriam-Webster, 2014). The request of the 
parent's opinion when developing the IEP causes one to think that they are not in a decision-making role. Further, the role of a consultant is that of a person who is called upon for professional advice or services to companies (Merriam-Webster, 2014). The definition of "consultant" causes one to think that the individual consulted is by an outside party, making them external to the decision making team. Consultation also elicits the meaning of talking to a person about a problem or question, or the act of looking for information (Merriam-Webster, 2014). Moreover, the use of the word "consulted" can be perceived as one being external to the issue. If a parent is consulted in the IEP development process, this may communicate that they are not in a decision making role or part of the IEP development team.

\section{IEP Development Heading}

An important area of the IEP document that both textually and visually conveys parent involvement is the "IEP Development Team" section. In the majority of the IEP templates, this section is typically entitled "IEP Development Team" or "IEP Developed by." In Figure 11, the "IEP Development Team" section excludes parents as contributing members because of the words "Staff Member" and "Position." Since the parents cannot be listed in this section, they are not documented as team members on the IEP. As Figure 11 demonstrates, the use of the heading "Staff Member" excludes the parents from being listed. 


\begin{tabular}{|c|c|}
\hline IEP Developed by: \\
\hline Staff Member & Position \\
\hline & \\
\hline & \\
\hline
\end{tabular}

\section{Figure 11: IEP development team}

Twenty-one out of 37 IEP templates position the "IEP Development Team" heading with "Staff Member." By labeling the heading "Staff Member," the ability for parents to be a part of the team is automatically marginalized. The remaining templates either contain a heading labeled "IEP Development Team" or it is left open-ended. The function of language in this particular instance is of great concern. Leaving the heading open-ended or labeling it "IEP Development Team," provides the opportunity for parents to be a part of the team. The recurring themes of parent involvement, participation, and equality come to mind when addressing the strategic labeling of this section. If parents are meant to be equal partners in creating the IEP, this section should not be textually directed to staff members.

\section{Assessment Section}

In the "Assessment" section the student's clinical assessment data is recorded. Due to the language employed, the section is to be completed by medical professionals or educators. As presented in Figure 12, the relevant assessment data requires medical results and diagnoses. Thus, the parent's personal assessments and observations of their child cannot be recorded in this section. 


\begin{tabular}{|c|l|l|}
\hline \multicolumn{2}{|l|}{ Relevant Assessment Data: } \\
\hline Date & & Summary of Results/Diagnosis \\
\hline & & \\
\hline & & \\
\hline & & \\
\hline & & \\
\hline
\end{tabular}

Figure 12: Relevant assessment data section

As Figure 12 shows, the heading "Summary of Results/Diagnosis" prevents parents from providing their personal assessments due to the medical connotations of the words "results" and "diagnosis". Many IEP templates use headings including but not limited to:

* Type of Assessment

* Clinical Assessment

* Relevant Assessment Data

* List relevant educational, detailed medical/health, psychological, speech/language, occupational, physiotherapy, and behavioural assessments.

As these examples demonstrate, the language employed in the "Assessment" section has the function to minimize the opportunity for parent input. 


\section{Analysis}

The primary research question guiding the MRP is as follows:

- How do the textual and visual constructions of the IEP document elicit parent involvement in individual education planning?

The textual and visual constructions of the IEP document elicit parent involvement in individual education planning through visual and linguistic cues. The notion of parent involvement is communicated through the presence of parent positioned elements within the IEP templates. Based on the research findings, parent involvement is communicated through the application of various document design principles. Because the IEP template acts as a form of genre, the power struggle that occurs during the IEP work process is realized (Popham, 2005). The textual construction of the IEP document does not present the parent as a primary focus. Rather, the textual construction may limit parent involvement due to the language employed and its perceived meaning. For example, the use of the word consulted does not position the parent as an equal participant in creating the IEP. Referring to the visual construction of the IEP, document design principles including order, hierarchy, and proximity, can be referred to in understanding the parent's presence in the IEP. Through application of these principles, the parent's involvement in the IEP work process appears to be low. For example, the low proximity between the "Parent Comment" section and the "IEP Education Plan" section visually communicates a weak relationship between these elements (Gribbons, 1991). 
Moreover, through the analysis of the IEP data set, the textual and visual constructions of the IEP document communicate low parent involvement in the work process.

Secondary Research Questions

- How do the roles of text and genre communicate the notion of parent involvement in individual education planning?

Text and genre play an important role in communicating the notion of parent involvement in individual education planning. The text and genre within each IEP help to understand how parent involvement may be controlled by the document's construction. Genre theory considers the intended communicative purpose, form, and content in the information transfer of a document (Kwasnik \& Crowston, 2005). In the IEP document the text may limit the parent's involvement in the IEP work process. The findings lead one to believe that the parent's level of involvement in the IEP document creation is minimal. Few IEP elements address the parent specifically, which may lead the parent to perceive their level of opportunity for involvement as minimal. Through conducting a semiotic analysis, the textual elements and genre of the IEP document transmit both a denoted message and a connoted message. The denoted message is the analogue itself, and the connoted message is the way in which the society communicates what it thinks (Barthes, 1977). Further, the textual elements within the IEP template can elicit both a literal meaning and a perceived meaning by the viewer. 16 of the 37 IEP templates do not contain a "Parent Comments" section which communicates low involvement due to low presence. The use of text that prevents the parent from being a member of the IEP Team 
is of concern. Using headings such as "Staff Member," automatically excludes the parent from being directly involved in the IEP Development Team.

- How does the IEP template either increase or decrease the opportunity for parent involvement?

The IEP template fails to increase the opportunity for parent involvement due to minimal visual and textual elements that require the parent's input. Beginning with visual elements, the IEP templates contain few areas designated for parent involvement. Referring to document design principles, including order, proximity, and prominence, the failure to increase the opportunity for parent involvement can be assessed. The order in which parent positioned elements are placed in the IEP cause them to appear last in the document. Because parent positioned elements appear within the last pages of the IEP, the amount of parent involvement is limited. If an opportunity for parent involvement is not presented until the end of the IEP, the amount of time spent on these sections is impacted. The lack of proximity of the "Parent Comments" section to the "IEP Education Plan" causes one to perceive these sections as unrelated. Thus, the contents of the "Parent Comments" section may not be considered when writing the "IEP Education Plan." The prominence of parent positioned elements within the IEP is low since the elements are not visually emphasized. Since there is no section designated solely for parent assessments, the IEP template fails to provide sufficient opportunity for parent involvement. In addition, the dramatic variation across the IEP templates is a large concern since many do not have any element positioned for parent completion. The majority of the IEP is to be completed by either educators or health care professionals. 
This raises concern since the parent is supposed to have an equal role in the creation of the IEP, but this role is not communicated on the IEP template.

The IEP Regulations in Ontario state the following must be included in the document:

- Specific educational expectations for the pupil.

An outline of the special education program and services.

* A statement of the methods by which progress will be reviewed.

* A postsecondary transition plan for pupils 14 years of age or older (Ministry of Education, 2004).

Surprisingly, there is no requirement for the inclusion of parent input, which may cause many school boards to fail to consider the parent's role in creating the IEP. The IEP work process must reflect to the fullest degree the potential for strong collaborative relationships whereby parents are equal partners (Pruitt, Wandry, \& Hollums, 1998). However, if the IEP template fails to increase the opportunity for parent involvement, the ideal of equal partnered relationships is unrealistic.

- How does the IEP template visually communicate the importance of parent involvement?

By using a semiotic content analysis and through the application of document design theories, parent involvement in the IEP can be assessed. Referring to document design principles including, order, hierarchy, proximity, and prominence, the overall visual prominence of parent positioned elements is low. The primary area within the IEP that is directed to the parent is the "Parent Comments" section. However, this section is 
only present in a limited number of the IEP's within the data set. The size of the "Parent Comments" field is often small, providing minimal space for the parent to address their concerns. The size of this section may be perceived as the parent having a minimal role in developing the IEP. Within the IEP, primary information is displayed as a prominent feature, whereas supplemental information is more subdued in visual presence (Horton, 1990). Since parent positioned elements lack visual emphasis, they may be perceived as supplemental information in the IEP. Visual cues found within each IEP template can communicate great meaning when perceived by the reader. The communicative purpose of a document can be analyzed according to four elements: the intended communicative effect, the document topic, the target group of the document, and the organizational goal as a social result (Lentz \& Henk, 2004). By referring to the intended communicate effect of the IEP, the importance of parent involvement is not apparent. Overall, the nominal presence of parent positioned elements in the IEP does not communicate the importance of parent involvement.

- Referring to semiotic analysis, does the visual construction of the IEP invite parent participation?

The concepts of both denotation and connotation can help to understand the notion of parent participation in the IEP. The denoted message is the analogue itself or the literal translation of both visual and textual elements (Barthes, 1977). The connoted message is the way in which a given element is perceived which relies upon societal norms and beliefs (Barthes, 1977). The visual construction of the IEPs evokes minimal 
presence of the parent in the IEP document. In addition, the presence of parent positioned elements within the IEP data set is minimal. The visual construction of the IEP presents minimal invitation for parent participation in the IEP work process due to minimal parent positioned elements. First, in the "IEP Development Team" section, the heading commonly states "Staff Member," which excludes parent participation. The "Assessment" section of the IEP does not provide the opportunity for parent input due to the language employed. The following serve as examples of the textual construction of the "Assessment" section: most sections are textually limiting by using phrases including the following:

\section{* "List relevant educational, detailed medical/health (hearing, vision, physical, neurological), psychological, speech/language, occupational, physiotherapy and behavioural assessments."}

In the IEP templates that contain the "Parent Comments" section, this acts as the sole opportunity for parent contributions to the IEP. However, since the "Parent Comments" section appears after the "IEP Education Plan", the parent's input may not be documented prior to the creation of the "IEP Education Plan." Document design theories including visual hierarchy and prominence help to understand the visual communication of the parent's role in the IEP. The marginal role of parent positioned elements visually communicates the minimal role a parent may play in creating the IEP. 


\section{Discussion}

After analyzing the visual and textual construction of the IEP, there are many aspects worthy of discussion in relation to parent involvement. In the literature, the discussion of parent involvement fails to consider the visual and textual construction of the IEP. By examining the visual and textual construction of the IEP templates, the role of the parent in the IEP work process can be better understood. Since the role of documents in the educative planning process is highly important, the role of parents in the IEP development process can be addressed.

The visual construction of the IEP communicates low parent involvement in the IEP work process due to several visual factors. Through the application of visual hierarchy theory, the design of the IEP can be understood in terms of the order of textual elements (Martin, 1989). Because the parent positioned elements appear last in the IEP, one may perceive the parent's role has minimal importance. The ordered position of these elements may help explain why the parent's participation in the IEP team meeting is marginalized. The literature emphasizes recurring concerns of parents feeling uninvolved, providing minimal contributions, and little effort to evaluate the parents' knowledge and perceptions of their child (Vaughn, 1988). Many of these findings may be largely attributed to the lack of parent positioned elements within the IEP. Common findings in the literature suggest that the IEP document is often filled out prior to the IEP team meeting. Since the majority of the IEP template does not require parent input, this issue may appear normal to team meeting facilitators. In addition, since time is mentioned as a 
predominant concern, school personnel can preplan an IEP meeting and present the plan to parents without their input (Weishaar, 2010). Since the "IEP Education Plan" is placed before the "Parent Comments" section in the IEP, this section can be completed without the input of parents.

The literature describes the importance of pedagogical documentation in providing the teacher's story of the child's understanding, enabling discussion and interpretation to generate ideas for further learning (Berdoussis, Guyevskey, \& Wien, 2011). Similar to pedagogical documentation, the IEP document communicates the story of the student's requirements in meeting their educational needs. Through analhe story of the parent's role in the IEP work process is also communicated. Graphic design principles and visual literacy are important to documentation in order to communicate clearly (Berdoussis, Guyevskey, \& Wien, 2011). The story of the parent's role in the IEP documentation process can be better understood with the application of graphic design principles. Due to the minimal amount of parent positioned elements in the IEP, the parent may have a smaller role in the work process as compared to educators and health professionals.

The connoted and denoted meanings of the IEP play a large role and one may perceive the parent to have a small role due to minimal visual presence. As defined by Barthes in the literature, the denoted message is the analogue itself, and the connoted message is the way in which the society communicates what it thinks (Barthes, 1977). The denoted messages of the IEP may be a lack of visual presence of the parent in the IEP process. In turn, the connoted meaning may cause one to interpret the minimal 
presence of the parent in the IEP as low parent involvement. The absence of the "Parent Comments" section in 16 of the 37 IEP's may elicit the connoted meaning that the parent is uninvolved. The visual construction of the IEP template may communicate low parent involvement in the IEP work process due to the characteristics of order, visual hierarchy, prominence, and proximity.

In seeking to understand the perceived meaning of the IEP, the number of potential connotative readings is due to individual differences in practical, national, cultural, and aesthetic knowledge (O'Donohoe, 1997). The connoted perception of the IEP document may impact the participant's actions in the IEP team meeting. Thus, the IEP template must be carefully altered in order to improve the visual representation of the parent's role. The elements presented in documents are methodically selected in order to achieve the desired connotative meaning (Pateman, 1980). It is necessary to consider if the parent is visually marginalized within the IEP in order to minimize their input during the IEP work process. Further, if the parent is meant to be an equal contributor to the IEP, this must also be represented in the IEP that is used to direct the team meeting.

The requirement for health-related, school-based support for children with special needs to integrate the work of families, health care professionals, and educators is not evident in the IEP templates $(\mathrm{Ng}, 2013)$. Due to the lack of parent positioned elements in the IEPs, it appears that health care professionals and educators play larger roles in the IEP work process. The few parent positioned elements in the IEP may cause the parent to have a smaller role in the IEP work process. Thus, the notion of equality in the IEP 
development process appears to be an ideal and not a reality as communicated in the IEP templates. Some professionals maintain the view that parents do not have the necessary information or expertise in decision making for constructive contributions to the IEP (Gilliam \& Coleman, 1981). This point of view appears in the IEP templates since parent contributions are not invited within the "Assessment" section of the IEP.

The "Assessment" section clearly shows the emphasis on the information provided by medical and education professionals. Literature discusses the notion that consultation with the student, parents, school staff, support personnel, and representatives of outside services are a valuable source of information in the development and the implementation of the IEP (Gallagher, 1995). In contrast, the information provided by parents does not receive as much emphasis through the communication of both visual and textual cues in the IEP. Although parents attend their child's IEP meeting, they often have no involvement in developing objectives, interventions, or methods of evaluation (Spann, 2008). The textual construction of the IEP may limit the level of parent involvement in the development of key IEP sections. Since the only IEP elements addressed for parent completion are the "Parent Comments" section and "Parent Consultation Log," little room is left for guaranteed input in the IEP.

The Ministry of Education published the document Individual Education Plans: Standards for Development, Program Planning, and Implementation in order to improve the consistency and the quality of the specialized education program (Ministry of Education, 2004). However, upon close examination of the IEP templates, it is clear that 
this document has failed to achieve consistency across all IEP templates in Ontario. In September 2002, the Ministry provided school boards with an IEP template and encouraged the revision of existing IEP's to capture the information presented in the template (Ministry of Ontario, 2004). However, this action has also failed to achieve consistency across all IEP templates in use. It is evident that because of the lack of standardization and regulation in the IEP there is great variation in the templates used across Ontario public school boards.

As the literature discusses, the parent involvement aspect of the IEP work process is strategically designed to modify the power relationship between parents and professionals to a more equitable level (Gallagher, 1995). However, if the IEP document acts as the gatekeeper throughout the IEP team meeting, it functions to lead the discussion process and conversation. Since the IEP positions the parent as unequal contributors through means of visual and textual cues, the same pattern may occur during the IEP team meeting. If professionals involved believe parents do not have expert information for contributions, parent involvement may be further marginalized (Gilliam \& Coleman, 1981)

In seeking to better understand the IEP document, the communicative purpose can be analyzed according to four elements: the intended communicative effect, the document topic, the target group of the document, and the organizational goal as a social result (Lentz \& Henk, 2004). The communicative purpose of the IEP is to document and track the needs of a student with special education requirements. During the IEP team meeting 
when the plan is established, it is argued that meaningful participation seldom occurs (Heatherington et al., 2010). If the IEP template includes few parent positioned elements, the meeting facilitator may lose sight of the need to include the parents as equal contributors. The organizational goal as a social result of the IEP document is to collaborate with the student, parents, school staff, support personnel, and representatives of outside services in the development and implementation of a student's IEP (Gallagher, 1995). However, the notion of equality is seldom practiced, which may be attributed to the visual and textual construction of the IEP. Parents, teachers, and health care professionals have all expressed concerns that despite all of the work that goes into the IEP process, their knowledge is not recognized or utilized effectively and efficiently $(\mathrm{Ng}$, 2013). The ineffective, inefficient utilization of a primary information source may be caused by the construction of the IEP template. The minimal amount of parent positioned elements may lead to the recurring outcome of low parent involvement because the document does not provide sufficient opportunity. 


\section{Recommendations}

Based on the findings and the analysis of the IEP templates, there are many recommendations that may help to increase the opportunity for parent involvement in the IEP work process. Form changes in the IEP should be driven by an improved conceptualization of their primary purpose and how they can be revised to fulfill their intended purpose for all educational team members (Giangreco, 1994). In addition, reorganizing or reformatting the IEP document may enable more effective communication practices (Giangreco, 1994). In order to increase the opportunity for parent involvement in the IEP, it is essential to create additional parent positioned fields. First, it is recommended that each IEP template contain a section labeled "Parent Input." In addition to parents' rights to contribute to the IEP development, they also provide critical information about the child that educators may not be aware of when developing an IEP (Cannon, 2011). In the "Parent Input" section, parents will be required to provide personal information pertaining to their concerns, observations, and recommendations for their child's educational needs. The placement of this section must be placed prior to the "IEP Education Plan" since this information should be considered when composing the education plan. In order to address the concern of variation across the IEP templates in Ontario, it is recommended that a standardized format be created and implemented. With a standard IEP format in use, this will ensure that each document contains the same informational fields. Research suggests that although parents may attend and participate in IEP meetings, few parents are directly involved in developing objectives, shaping 
educational programs, or deciding on assessment procedures (Lynch \& Stein, 1982). Common findings in the literature suggest that the IEP document is often filled out prior to the IEP team meeting. Time as a predominant concern may cause school personnel to preplan an IEP meeting and present the IEP plan to the parents whereby parents must react to the recommendations (Weishaar, 2010). According to the IEP Standards, parents provide information about the child's personality, development, and learning, but this does not necessarily lead to shared decision making in the education process (Underwood, 2010). Revising the IEP template and implementing a standardized template in Ontario may help to increase parent involvement in the IEP work process. 


\section{Limitations and Future Study}

The semiotic content analysis of the IEP templates acts as an interpretative exploration of the construction of the educational documents. The nature of a semiotic analytical approach of the IEP is open to subjectivity from the researcher's perspective. Exploring the perceived connoted and denoted meanings of key IEP elements may be open to varying interpretations. Since this research study seeks to examine the visual and textual construction of the IEP by taking the perspective of the parent, the interpretations may be different for each viewer. In order to limit the level of subjectivity in the research process, the IEP documents have been assessed based on the presence and communication of parent positioned elements. Since the study consists of a semiotic content analysis, parents were not surveyed for their opinions on this matter. Thus, the scope of this research study does not include the perceptions and opinions of the parents themselves when viewing the IEP document.

The results and analysis of this study do not represent the thoughts or opinions of the parents, but simply bring to light potential issues in the IEP document's construction. This research study does not seek to illustrate the IEP team meeting process, nor does it seek to represent the actions of those involved in completing the IEP. Instead, this research study aims to illustrate the requirement for revisiting the visual and textual construction of the IEP. Discussing how the document itself communicates various themes both visually and textually may help to improve the document for future use. Future study in addressing the visual and textual construction of the IEP document will 
require interviewing and surveying parents. Conducting a survey that gathers parents' perceptions of the IEP document will help to further understand the communicative effect of the visual and textual constructions. In addition, by gaining further insight into this critical issue, a standardized IEP template can be created in order to correct the noteworthy issues. 


\section{Conclusion}

In conclusion, the semiotic content analysis of the IEP templates acts as an interpretative exploration of the construction of the educational documents. As found in the literature, the notion of parent involvement in the IEP work process is highly controversial. Researchers note parents as highly important information sources in creating the IEP, but high involvement seldom occurs. In order to investigate the issue of parent involvement, a semiotic analytical approach was used that combines both semiotic theory and document design theory. This study seeks to examine the visual and textual construction of the IEP. By taking the perspective of the parent the interpretations may be different for each viewer. The results and analysis of this study do not represent the thoughts or opinions of the parents, but simply bring to light potential issues in the IEP document's construction.

Upon completion of the research process, the illustration of key issues found in the IEP may require revisiting the visual and textual constructions. Discussing how the document itself communicates various themes both visually and textually will help to improve the document for future use. For future study in addressing the visual and textual construction of the IEP, it will be necessary to interview and survey parents. By gaining further insight into this critical issue, a standardized IEP template can be created in order to increase parent involvement. The recommendation to create additional parent positioned fields will increase the opportunity for parent involvement in the IEP work process. Further, through completion of this explorative research study, it is hoped that 
the visual and textual constructions of the IEP template will be revisited in order to improve upon parent involvement in the work process. 


\section{References}

Abramson, M., Willson, V.L., Yoshida, R. K., \& Hagerty, G. (1983). Parents' perceptions of their learning disabled child's educational performance. Learning Disability Quarterly, 6, 184-194. Retrieved from http://www.jstor.org.ezproxy.lib.ryerson.ca/stable/1510796

Bacon, J., \&Causton-Theoharis, J. (2013). 'It should be teamwork': a critical investigation of school practices and parent advocacy in special education. International Journal of Inclusive Education, 17(7), 682-699. Retrieved from http://www.tandfonline.com/doi/abs/10.1080/13603116.2012.708060

Barrett, F., Thomas, G., \& Hocevar, S. (1995). The central role of discourse in large-scale change: A social construction perspective. The Journal of Applied Behavioral Science, 31(3), 352-372. Retrieved from

http://journals 1.scholarsportal.info.ezproxy.lib.ryerson.ca/details/00218863/v31i0003/ 352 tcrodilcascp.xml

Barthes, R. (1977). Image music text. London, England: Fontana Press.

Bell, P., \& Milic, M. (2002). Goffman's gender advertisements revisited: Combining content analysis with semiotic analysis. Visual Communication, 1(2), 203222.doi:10.1177/147035720200100205

http://journals 1.scholarsportal.info.ezproxy.lib.ryerson.ca/details/14703572/v01i0002/ 203 ggarccawsa.xml

Berdoussis, N., Guyevskey , V., \& Wien, C. (2011). Learning to document in reggio inspired education. Early Childhood Research \& Practice,13(2), Retrieved from 
http://go.galegroup.com.ezproxy.lib.ryerson.ca/ps/i.do?action=interpret\&id=GALE|A2 $76438062 \& v=2.1 \& u=r p u \_m a i n \& i t=r \& p=A O N E \& s w=w \&$ authCount $=1$

Cannon, Y. (2011). Who's the boss?: The need for thoughtful identification of the client(s) in special education cases. The American University Journal of Gender, Social Policy \& the Law,20(1), 1-79. Retrieved from http://search.proquest.com.ezproxy.lib.ryerson.ca/docview/922948857

Chabotar, K., \& Montgomery, S. (1975). Organizational Documents as Indicators of Effectiveness of Educational Planning. The Journal of Experimental Education, Vol. 43, No. 4 (Summer, 1975), pp. 53-66 Retrieved from http://www.jstor.org.ezproxy.lib.ryerson.ca/stable/20151048

Dabkowski, D. (2004). Encouraging active parent participation in iep team meetings. TEACHING Exceptional Children, 36(3), 34-39. Retrieved from http://www.metapress.com.ezproxy.lib.ryerson.ca/content/u617174685w6825u/?volu $\underline{m e}=36 \&$ spage $=34 \&$ issn $=0040-0599 \&$ issue $=3 \&$ genre $=$ article

Finn, A., \&Kushmerick, N. (2006). Learning to classify documents according to genre. Journal of the American Society for Information Science and Technology, 57(11), 1506-1518. Retrieved from http://journals1.scholarsportal.info.ezproxy.lib.ryerson.ca/details/15322882/v57i0011/ 1506_ltcdatg.xml

Fish, W. (2008). The iep meeting: Perceptions of parents of students who receive special education services. Preventing School Failure: Alternative Education for Children and Youth, 53(1), 8-14. Retrieved from 
http://journals2.scholarsportal.info.ezproxy.lib.ryerson.ca/details/1045988x/v53i0001/ 8 timpopswrses.xml

Gallagher, J. (1995). Lessons learned from implementation of the iep : Applications to theifsp. Topics in Early Childhood Special Education, 15(3), 353-378. Retrieved from http://journals1.scholarsportal.info.ezproxy.lib.ryerson.ca/details/02711214/v15i0003/ 353_llfioti.xml

Gerstein, S. (2004). Benefits and influences of parent involvement for children with learning disabilities. (Order No. NR06300, McGill University (Canada)). ProQuest Dissertations and Theses, , 107-107 p. Retrieved from http://ezproxy.lib.ryerson.ca/login?url=http://search.proquest.com/docview/305074685 ?accountid=13631. (305074685).

Giangreco, M., Dennis, R., Edelman, S., \& Cloninger, C. (1994). Dressing your ieps for the general education climate. Remedial and Special Education, 15(5), 288-296. Retrieved from http://journals2.scholarsportal.info.ezproxy.lib.ryerson.ca/details/07419325/v15i0005/ 288 dyiftgofswmd.xml

Gilgun, J. (1999). Fingernails painted red: A feminist, semiotic analysis of a "Hot" text. Qualitative Inquiry, 5(2), 181-207.doi:10.1177/107780049900500202 http://journals2.scholarsportal.info.ezproxy.lib.ryerson.ca/details/10778004/v05i0002/ $181 \_$fprafsaoat.xml?q=semiotic\&search_in $=$anywhere\&op=AND\&q=qualitative + inqu iry\&search_in=JOURNAL\&date_from $=\&$ date $\_$to $=\&$ sort $=$ relevance $\&$ sub $=$ 
Gilliam, J., \& Coleman, M. (1981). Who influences iep committee decisions?. Exceptional Children,47(8), 642-644. Retrieved from http://www.ncbi.nlm.nih.gov/pubmed/6453012

Gribbons, W. M. (1991). Visual literacy in corporate communication: some implications for information design. Professional Communication, IEEE Transactions, 34(1), 4250. Retrieved from $\underline{\text { http://ieeexplore.ieee.org.ezproxy.lib.ryerson.ca/xpls/abs all.jsp?arnumber }=68427 \& t a}$ $\mathrm{g}=1$

Hetherington, S., Durant-Jones, L., Johnson, K., Nolan, K., Smith, E., Taylor-Brown, S., \& Tuttle, J. (2010). The lived experiences of adolescents with disabilities and their parents in transition planning.Focus on Autism and Other Developmental Disabilities, 25(3), 163-172. Retrieved from http://journals1.scholarsportal.info.ezproxy.lib.ryerson.ca/details/10883576/v25i0003/ 163 tleoawatpitp.xml

Horton, W., "Visual rhetoric for online documents," Professional Communication, IEEE Transactions on, vol.33, no.3, pp.108,114, Sep 1990 doi: 10.1109/47.59084 URL: http://ieeexplore.ieee.org/stamp/stamp.jsp?tp=\&arnumber=59084\&isnumber=21 $\underline{50}$

Jung, A. W. (2011). Individualized education programs (IEPs) and barriers for parents from culturally and linguistically diverse backgrounds.Multicultural Education, 18(3), 21-25. Retrieved from 
http://ezproxy.lib.ryerson.ca/login?url=http://search.proquest.com/docview/926978273 ?accountid $=13631$

Kessous, A., \& Roux, E. (2008). A semiotic analysis of nostalgia as a connection to the past. Qualitative Market Research: An International Journal, 11(2), 192-212.

doi: $10.1108 / 13522750810864440$

http://journals2.scholarsportal.info.ezproxy.lib.ryerson.ca/details/13522752/v11i0002/

192_asaonaacttp.xml?q=semiotic\&search_in=TITLE\&op=AND\&q=qualitative+\&sea $\underline{\text { rch } \_ \text {in }=J O U R N A L \& \text { date from }=\& \text { date } \_ \text {to }=\& \text { sort }=\text { relevance } \& \text { sub }=}$

Kwasnik, B. H., \& Crowston, K. (2005). Introduction to the special issue: Genres of digital documents.Information Technology \& People, 18(2), 76-88. Retrieved from http://ezproxy.lib.ryerson.ca/login?url=http://search.proquest.com/docview/222394042 ?accountid=13631

Landmark, L., \& Zhang, D. (2013). Compliance and practices in transition planning: A review of individualized education program documents. Remedial and Special Education, 34(2), 113-125. Retrieved from http://journals2.scholarsportal.info.ezproxy.lib.ryerson.ca/details/07419325/v34i0002/ 113 capitproiepd.xml

Lentz, L., \&Henk, P. M. (2004). Functional analysis for document design. Technical Communication, 51(3), 387-398. Retrieved from http://ezproxy.lib.ryerson.ca/login?url=http://search.proquest.com/docview/220989729 ?accountid $=13631$ 
http://search.proquest.com.ezproxy.lib.ryerson.ca/docview/220989729

Lynch, E., \& Stein, R. (1982). Perspectives on parent participation in special education. Exceptional Education Quarterly, 3(2), 56-63. Retrieved from http://psycnet.apa.org/psycinfo/1982-31369-001

Martin, M., "The semiology of documents," Professional Communication, IEEE

Transactions on, vol.32, no.3, pp.171,177, Sep 1989 doi: 10.1109/47.31625

URL: http://ieeexplore.ieee.org/stamp/stamp.jsp?tp=\&arnumber=31625\&isnumber=13

72

Merriam-Webster. (2014). Consult. In Merriam-Webster Dictionary. Retrieved from http://www.merriam-webster.com/dictionary/consult

Merriam-Webster. (2014). Consultant. In Merriam-Webster Dictionary. Retrieved from http://www.merriam-webster.com/dictionary/consultant

Merriam-Webster. (2014). Consultation. In Merriam-Webster Dictionary. Retrieved from http://www.merriam-webster.com/dictionary/consultation

Ministry of Education.Ontario Ministry of Education, (2000).Individual education plans: Standards for development, program planning, and implementation. Retrieved from Queen's Printer for Ontario website:

http://www.edu.gov.on.ca/eng/general/elemsec/speced/iep/iep.pdf 
Ministry of Education.Ontario Ministry of Education, (2004).The individual education plan: A resource guide. Retrieved from Queen's Printer for Ontario website: http://www.edu.gov.on.ca/eng/general/elemsec/speced/guide/resource/iepresguid.pdf Mur-Veeman, A., \& van Raak, P. (2008). Comparing integrated care policy in europe: Does policy matter?.Health Policy, 85(2), 172-183. Retrieved from http://journals2.scholarsportal.info.ezproxy.lib.ryerson.ca/details/01688510/v85i0002/ 172 cicpiedpm.xml

Ng, S., Stooke, R., Regan, S., Hibbert, K., Schryer, C., Phelan, S., \&Lingard, L. (2013). An institutional ethnography inquiry of health care work in special education: a research protocol. International Journal Of Integrated Care, 13(3). Retrieved fromhttp://www.ijic.org/index.php/ijic/article/view/URN\%3ANBN\%3ANL\%3AUI\%3 A10-1-114741/2031

Nguyen, X. (2012). On the use of visual methodologies in educational policy research. South African Journal of Education, 32(4), 479-493. Retrieved from http://www.scielo.org.za/scielo.php?script=sci_serial\&pid=02560100\&lng=en\&nrm=iso

Noth, W. (1990). Handbook of semiotics. Bloomington: Indiana University Press.

Nuessel, F. (2012). The semiotics of communication. Semiotica: Journal of the International Association for Semiotic Studies, 189(1), 271-285. Retrieved from http://go.galegroup.com.ezproxy.lib.ryerson.ca/ps/i.do?action=interpret\&id=GALE|A3 $44703907 \& v=2.1 \& u=r p u \_m a i n \& i t=r \& p=A O N E \& s w=w \&$ authCount $=1$ 
O'Donohoe, S. (1997). Raiding the postmodern pantry advertising intertextuality and the young adult audience.European Journal of Marketing, 31(3), 234-253. Retrieved from http://ezproxy.lib.ryerson.ca/login?url=http://search.proquest.com/docview/237020198 ?accountid=13631

Ontario Coalition for Inclusive Education. (2004, November). What does the revised ministry of education iep resource guide mean for students, parents and educators seeking effective inclusive education?. Retrieved from http://www.inclusiveeducation.ca/resources/documents/IEP_Analysis.pdf

Pateman, T. (1980). How to do things with images: An essay on the pragmatics of advertising. Theory and Society, 9(4), 603-622. Retrieved from http://www.jstor.org.ezproxy.lib.ryerson.ca/stable/656929

Popham, S. (2005). Forms as boundary genres in medicine, science, and business. Journal of Business and Technical Communication, 19(3), 279-303. Retrieved from http://journals1.scholarsportal.info.ezproxy.lib.ryerson.ca/details/10506519/v19i0003/ 279_fabgimsab.xml

Prior, L. (2003). Using documents in social research. Thousand Oaks, CA: Sage Publications.

Pruitt, P., Wandry, D., \&Hollums, D. (1998). Listen to us! parents speak out about their interactions with special educators. Preventing School Failure: Alternative Education for Children and Youth, 42(4), 161-166. doi:10.1080/10459889809603732 http://journals1.scholarsportal.info.ezproxy.lib.ryerson.ca/details/1045988x/v42i0004/ 161 ltupsoatiwse.xml 
Rastier, F. (2012). Text semiotics: Between philology and hermeneutics - from the document to the work.Semiotica: Journal of the International Association for Semiotic Studies, 2012(192), 99-122. Retrieved from

http://web.b.ebscohost.com.ezproxy.lib.ryerson.ca/ehost/pdfviewer/pdfviewer?sid=7e2 b7245-6ec1-4dd4-ba7f-b56a8ffbddd0@sessionmgr198\&vid=2\&hid=121

Rose, G. (2012). Visual methodologies: An introduction to researching with visual materials (3rd ed. ed.). Thousand Oaks, Calif.: SAGE.

Rosenquist, C. (2012). Visual form, ethics, and a typology of purpose: Teaching effective information design. Business Communication Quarterly, 75(1), 45-

60.doi:10.1177/1080569911428670

http://journals2.scholarsportal.info.ezproxy.lib.ryerson.ca/details/10805699/v75i0001/ 45 _vfeaatopteid.xml

Salembier, G., \& Furney, K. (1997). Facilitating participation: Parents. Career Development for Exceptional Individuals, 20(1), 29-42. Retrieved from http://journals1.scholarsportal.info.ezproxy.lib.ryerson.ca/details/08857288/v20i0001/ 29 fpppotiitipp.xml

Spann, S., Kohler, F., \&Soenksen, D. (2003). Examining parents' involvement in and perceptions of special education services: An interview with families in a parent support group.Focus on Autism and Other Developmental Disabilities, 18(4), 228-237. Retrieved from http://journals1.scholarsportal.info.ezproxy.lib.ryerson.ca/details/10883576/v18i0004/ $\underline{228 \text { epiiaposes.xml }}$ 
Steere, D., \& DiPipi-Hoy, C. (2013). Coordination in transition planning: The IEP/IPE interface. Journal of Applied Rehabilitation Counseling, 44(1), 4-11. Retrieved from http://ezproxy.lib.ryerson.ca/login?url=http://search.proquest.com/docview/134694312 9? accountid=13631

Törrönen, J. (2002). Semiotic theory on qualitative interviewing using stimulus texts. Qualitative Research, 2(3), 343-362.doi:10.1177/146879410200200304 http://journals2.scholarsportal.info.ezproxy.lib.ryerson.ca/details/14687941/v02i0003/ 343 stoqiust.xml?q=semiotic\&search_in=TITLE\&op=AND\&q=qualitative+\&search $\underline{\text { in }=\text { JOURNAL\&date from }=\& \text { date } \text { to }=\& \text { sort }=\text { relevance } \& \text { sub }}=$

Underwood, K. (2010). Involving and engaging parents of children with ieps. . Exceptionality Education International, 20(1), 18-36. Retrieved from https://owa.smh.ca/owa/redir.aspx?C=9Ka0cxsmWkSxhKKJVbsbCAasDX3L79AIm5 qfpgx8com7gzyPS4UmALMoHAS-

cKqbA9djETjXfoE.\&URL=http://bf4dv7zn3u.search.serialssolutions.com.myaccess.li brary.utoronto.ca/?ctx_ver=Z39.88-2004\&ctx_enc=info\%3Aofi $\% 2$ Fenc $\% 3 \mathrm{AUTF}-$

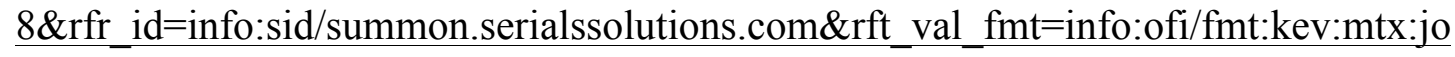
urnal\&rft.genre $=$ article\&rft.atitle $=$ Involving + and + Engaging + Parents + of + Children + wi $\underline{\text { th}}+$ IEPs\&rft.jtitle $=$ Exceptionality + Education + International\&rft.au $=$ Underwood $\% 2 \mathrm{C}+$ $\underline{\text { Kathryn\&rft.date }=2010 \& r f t . p u b=\text { Exceptionality }+ \text { Education }+ \text { International\&rft.issn }=19}$ $\underline{18-}$ 5227\&rft.volume $=20 \&$ rft.issue $=1 \&$ rft.spage $=18 \&$ rft.epage $=36 \&$ rft.externalDocID $=$ EJ 
$\underline{931233}$

Van Haren, B., \& Fiedler, C. (2008). Support and empower families of children with disabilities. Intervention in School and Clinic, 43(4), 231-235.

doi:10.1177/1053451208314908

http://journals2.scholarsportal.info.ezproxy.lib.ryerson.ca/details/10534512/v43i0004/

231_saefocwd.xml

Vaughn, S., Bos, C., Harrell, J., \&Lasky, B. (1988). Parent participation in the initial placement/iep conference ten years after mandated involvement.Journal of Learning Disabilities, 21(2), 82-89. Retrieved from

http://journals2.scholarsportal.info.ezproxy.lib.ryerson.ca/details/00222194/v21i0002/ 82 ppitipctyami.xml

Wagner, M., Newman, L., Cameto, R., Javitz, H., \& Valdes, K. (2012). A national picture of parent and youth participation in iep and transition planning meetings. Journal of Disability Policy Studies, 23(3), 140-155. Retrieved from http://journals2.scholarsportal.info.ezproxy.lib.ryerson.ca/details/10442073/v23i0003/ 140 anpopaiiatpm.xml

Warner, J. (1990).Semiotics, information science, documents, and computers.Journal of Documentation, 46(1), 16-32. Retrieved from http://www.emeraldinsight.com.ezproxy.lib.ryerson.ca/journals.htm?articleid=165009 2\&show $=$ abstract

Weishaar, P. (2010). Twelve ways to incorporate strengths-based planning into the iep 
process. The Clearing House: A Journal of Educational Strategies, Issues and Ideas, 83(6), 207-210. Retrieved from

http://journals2.scholarsportal.info.ezproxy.lib.ryerson.ca/details/00098655/v83i0006/207 twtispitip.xml 


\section{Appendix A: Raw Data Table}

\begin{tabular}{|c|c|c|c|c|c|c|}
\hline Schoolboard & $\begin{array}{l}\text { Parents } \\
\text { Comments }\end{array}$ & $\begin{array}{l}\text { Parent } \\
\text { Comments } \\
\text { Location }\end{array}$ & $\begin{array}{l}\text { Page } \\
\#\end{array}$ & $\begin{array}{l}\text { Comments } \\
\text { After IEP } \\
\text { Results/Plan }\end{array}$ & $\begin{array}{l}\text { Text } \\
\text { Box, } \\
\text { Fillable } \\
\text { Lines }\end{array}$ & $\begin{array}{l}\text { Parent } \\
\text { Signature }\end{array}$ \\
\hline $\begin{array}{l}\text { Avon } \\
\text { Maitland }\end{array}$ & no & no & $\mathrm{n} / \mathrm{a}$ & $\mathrm{n} / \mathrm{a}$ & $\mathrm{n} / \mathrm{a}$ & no \\
\hline $\begin{array}{l}\text { Bluewater } \\
\text { BWDSB }\end{array}$ & no & no & $\mathrm{n} / \mathrm{a}$ & $\mathrm{n} / \mathrm{a}$ & $\mathrm{n} / \mathrm{a}$ & no \\
\hline $\begin{array}{l}\text { Niagara } \\
\text { DSBN }\end{array}$ & yes & last page & $\begin{array}{l}5 \text { of } \\
5\end{array}$ & yes & lines & yes \\
\hline $\begin{array}{l}\text { Ontario } \\
\text { NorthEast }\end{array}$ & no & no & $\mathrm{n} / \mathrm{a}$ & $\mathrm{n} / \mathrm{a}$ & $\mathrm{n} / \mathrm{a}$ & no \\
\hline Durham & yes & last page & $\begin{array}{l}5 \text { of } \\
5 \\
\end{array}$ & yes & $\begin{array}{l}\text { text } \\
\text { box - } \\
\text { small }\end{array}$ & yes \\
\hline $\begin{array}{l}\text { Halton } \\
\text { HDSB }\end{array}$ & no & no & $\mathrm{n} / \mathrm{a}$ & $\mathrm{n} / \mathrm{a}$ & $\mathrm{n} / \mathrm{a}$ & no \\
\hline $\begin{array}{l}\text { Kawartha } \\
\text { KPRDSB }\end{array}$ & yes & last page & $\begin{array}{l}7 \text { of } \\
9\end{array}$ & yes & lines & yes \\
\hline $\begin{array}{l}\text { Keewatin } \\
\text { KPDSB }\end{array}$ & yes & last page & $\begin{array}{l}4 \text { of } \\
4\end{array}$ & yes & $\begin{array}{l}\text { text } \\
\text { box - } \\
\text { small }\end{array}$ & yes \\
\hline
\end{tabular}




\begin{tabular}{|c|c|c|c|c|c|c|}
\hline $\begin{array}{l}\text { Lambton } \\
\text { LKDSB }\end{array}$ & no & no & $\mathrm{n} / \mathrm{a}$ & $\mathrm{n} / \mathrm{a}$ & $\mathrm{n} / \mathrm{a}$ & yes \\
\hline $\begin{array}{l}\text { Limestone } \\
\text { LDSB }\end{array}$ & yes & end of iep & $\begin{array}{l}4 \text { of } \\
4\end{array}$ & yes & $\begin{array}{l}\text { text } \\
\text { box - } \\
\text { small }\end{array}$ & yes \\
\hline $\begin{array}{l}\text { Near North } \\
\text { NNDSB }\end{array}$ & yes & last page & $\begin{array}{l}4 \text { of } \\
5\end{array}$ & no & $\begin{array}{l}\text { text } \\
\text { box - } \\
\text { small }\end{array}$ & yes \\
\hline $\begin{array}{l}\text { Ottawa- } \\
\text { Carleton } \\
\text { OCDSB }\end{array}$ & yes & end of iep & $\begin{array}{l}5 \text { of } \\
7\end{array}$ & yes & $\begin{array}{l}\text { text } \\
\text { box - } \\
\text { small }\end{array}$ & yes \\
\hline $\begin{array}{l}\text { Rainbow } \\
\text { RDSB }\end{array}$ & no & no & $\mathrm{n} / \mathrm{a}$ & $\mathrm{n} / \mathrm{a}$ & $\mathrm{n} / \mathrm{a}$ & yes \\
\hline $\begin{array}{l}\text { Rainy River } \\
\text { RRDSB }\end{array}$ & no & no & $\mathrm{n} / \mathrm{a}$ & $\mathrm{n} / \mathrm{a}$ & $\mathrm{n} / \mathrm{a}$ & no \\
\hline $\begin{array}{l}\text { Renfrew } \\
\text { RCDSB }\end{array}$ & yes & $\begin{array}{l}\text { 2nd last } \\
\text { page }\end{array}$ & $\begin{array}{l}5 \text { of } \\
6\end{array}$ & yes & lines & yes \\
\hline $\begin{array}{l}\text { Toronto } \\
\text { TDSB }\end{array}$ & yes & last page & $\begin{array}{l}5 \text { of } \\
6 \\
\end{array}$ & yes & $\begin{array}{l}\text { text } \\
\text { box - } \\
\text { small }\end{array}$ & yes \\
\hline $\begin{array}{l}\text { Trillium } \\
\text { Lakelands } \\
\text { TLDSB }\end{array}$ & yes & last page & $\begin{array}{l}6 \text { of } \\
6\end{array}$ & yes & lines & yes \\
\hline
\end{tabular}




\begin{tabular}{|c|c|c|c|c|c|c|}
\hline $\begin{array}{l}\text { Waterloo } \\
\text { WRDSB }\end{array}$ & yes & last page & $\begin{array}{l}10 \\
\text { of } \\
10\end{array}$ & yes & lines & yes \\
\hline $\begin{array}{l}\text { York } \\
\text { YRDSB }\end{array}$ & no & no & $\mathrm{n} / \mathrm{a}$ & $\mathrm{n} / \mathrm{a}$ & $\mathrm{n} / \mathrm{a}$ & yes \\
\hline $\begin{array}{l}\text { Algonquin } \\
\text { Lakeshore } \\
\text { Catholic } \\
\text { ALCDSB }\end{array}$ & no & no & $\mathrm{n} / \mathrm{a}$ & $\mathrm{n} / \mathrm{a}$ & $\mathrm{n} / \mathrm{a}$ & no \\
\hline $\begin{array}{l}\text { Bruce-Grey } \\
\text { Catholic }\end{array}$ & yes & last page & $\begin{array}{l}6 \text { of } \\
6\end{array}$ & yes & $\begin{array}{l}\text { text } \\
\text { box - } \\
\text { small }\end{array}$ & yes \\
\hline $\begin{array}{l}\text { Halton } \\
\text { Catholic }\end{array}$ & no & no & $\mathrm{n} / \mathrm{a}$ & $\mathrm{n} / \mathrm{a}$ & $\mathrm{n} / \mathrm{a}$ & no \\
\hline $\begin{array}{l}\text { Hamilton- } \\
\text { Wentworth } \\
\text { Catholic }\end{array}$ & yes & $\begin{array}{l}\text { separate } \\
\text { form }\end{array}$ & $\begin{array}{l}4 \text { of } \\
4\end{array}$ & yes & lines & yes \\
\hline $\begin{array}{l}\text { Huron- } \\
\text { Superior } \\
\text { Catholic } \\
\end{array}$ & no & no & $\mathrm{n} / \mathrm{a}$ & $\mathrm{n} / \mathrm{a}$ & $\mathrm{n} / \mathrm{a}$ & no \\
\hline $\begin{array}{l}\text { Kenora } \\
\text { Catholic }\end{array}$ & yes & last page & $\begin{array}{l}7 \text { of } \\
7\end{array}$ & yes & $\begin{array}{l}\text { text } \\
\text { box - } \\
\text { small } \\
\end{array}$ & yes \\
\hline $\begin{array}{l}\text { London } \\
\text { District } \\
\text { Catholic }\end{array}$ & no & no & $\mathrm{n} / \mathrm{a}$ & $\mathrm{n} / \mathrm{a}$ & $\mathrm{n} / \mathrm{a}$ & yes \\
\hline $\begin{array}{l}\text { Niagara } \\
\text { Catholic }\end{array}$ & no & no & $\mathrm{n} / \mathrm{a}$ & $\mathrm{n} / \mathrm{a}$ & $\mathrm{n} / \mathrm{a}$ & no \\
\hline $\begin{array}{l}\text { Northeastern } \\
\text { Catholic }\end{array}$ & no & no & $\mathrm{n} / \mathrm{a}$ & $\mathrm{n} / \mathrm{a}$ & $\mathrm{n} / \mathrm{a}$ & yes \\
\hline
\end{tabular}




\begin{tabular}{|c|c|c|c|c|c|c|}
\hline $\begin{array}{l}\text { Northwest } \\
\text { Catholic }\end{array}$ & yes & $\begin{array}{l}\text { separate } \\
\text { form }\end{array}$ & $\begin{array}{l}3 \text { of } \\
3\end{array}$ & yes & $\begin{array}{l}\text { text } \\
\text { box - } \\
\text { small }\end{array}$ & yes \\
\hline $\begin{array}{l}\text { Ottawa } \\
\text { Catholic } \\
\text { Elementary }\end{array}$ & yes & $\begin{array}{l}\text { towards } \\
\text { end }\end{array}$ & $\begin{array}{l}4 \text { of } \\
6 \\
\end{array}$ & no & $\begin{array}{l}\text { text } \\
\text { box }\end{array}$ & yes \\
\hline $\begin{array}{l}\text { Ottawa } \\
\text { Catholic } \\
\text { Secondary }\end{array}$ & yes & last page & $\begin{array}{l}4 \text { of } \\
6\end{array}$ & no & $\begin{array}{l}\text { text } \\
\text { box }\end{array}$ & yes \\
\hline $\begin{array}{l}\text { Simcoe } \\
\text { Muskoka } \\
\text { Catholic }\end{array}$ & yes & last page & $\begin{array}{l}5 \text { of } \\
5 \\
\end{array}$ & yes & $\begin{array}{l}\text { lines - } \\
\text { very } \\
\text { small }\end{array}$ & yes \\
\hline $\begin{array}{l}\text { St. Clair } \\
\text { Catholic }\end{array}$ & no & no & $\mathrm{n} / \mathrm{a}$ & $\mathrm{n} / \mathrm{a}$ & $\mathrm{n} / \mathrm{a}$ & no \\
\hline $\begin{array}{l}\text { Sudbury } \\
\text { Catholic }\end{array}$ & yes & last page & $\begin{array}{l}3 \text { of } \\
3\end{array}$ & yes & lines & yes \\
\hline $\begin{array}{l}\text { Thunder Bay } \\
\text { Catholic }\end{array}$ & yes & $\begin{array}{l}\text { separate } \\
\text { form }\end{array}$ & $\begin{array}{l}5 \text { of } \\
5\end{array}$ & yes & $\begin{array}{l}\text { text } \\
\text { box - } \\
\text { small }\end{array}$ & yes \\
\hline $\begin{array}{l}\text { Waterloo } \\
\text { Catholic }\end{array}$ & yes & $\begin{array}{l}\text { separate } \\
\text { form }\end{array}$ & $\begin{array}{l}7 \text { of } \\
7\end{array}$ & yes & lines & yes \\
\hline $\begin{array}{l}\text { York } \\
\text { Catholic }\end{array}$ & no & no & $\mathrm{n} / \mathrm{a}$ & $\mathrm{n} / \mathrm{a}$ & $\mathrm{n} / \mathrm{a}$ & no \\
\hline
\end{tabular}




\begin{tabular}{|c|c|c|c|c|c|c|}
\hline Schoolboard & $\begin{array}{l}\text { Parent } \\
\text { Signature } \\
\text { Location } \\
\text { (Page \#) }\end{array}$ & $\begin{array}{l}\text { IEP } \\
\text { Developed } \\
\text { by }\end{array}$ & $\begin{array}{l}\text { Parent } \\
\text { Consultation } \\
\text { Checklist }\end{array}$ & $\begin{array}{l}\text { Log of } \\
\text { Parent } \\
\text { Consultation }\end{array}$ & $\begin{array}{l}\text { "I was } \\
\text { consulted } \\
\text { in IEP" }\end{array}$ & $\begin{array}{l}\text { Sources } \\
\text { Consulted }\end{array}$ \\
\hline $\begin{array}{l}\text { Avon } \\
\text { Maitland }\end{array}$ & $\mathrm{n} / \mathrm{a}$ & $\begin{array}{l}\text { Staff } \\
\text { Member }\end{array}$ & no & no & no & $\begin{array}{l}\text { open- } \\
\text { ended }\end{array}$ \\
\hline $\begin{array}{l}\text { Bluewater } \\
\text { BWDSB }\end{array}$ & $\mathrm{n} / \mathrm{a}$ & open-ended & no & yes & no & $\begin{array}{l}\text { open- } \\
\text { ended }\end{array}$ \\
\hline $\begin{array}{l}\text { Niagara } \\
\text { DSBN }\end{array}$ & 5 of 5 & $\begin{array}{l}\text { Staff } \\
\text { Member }\end{array}$ & yes & yes & yes & box list \\
\hline $\begin{array}{l}\text { Ontario } \\
\text { NorthEast }\end{array}$ & $\mathrm{n} / \mathrm{a}$ & $\begin{array}{l}\text { Staff } \\
\text { Member }\end{array}$ & no & yes & no & no \\
\hline Durham & 5 of 5 & staff member & yes & yes & no & $\begin{array}{l}\text { open- } \\
\text { ended }\end{array}$ \\
\hline $\begin{array}{l}\text { Halton } \\
\text { HDSB } \\
\end{array}$ & $\mathrm{n} / \mathrm{a}$ & staff member & no & no & no & $\begin{array}{l}\text { open- } \\
\text { ended }\end{array}$ \\
\hline $\begin{array}{l}\text { Kawartha } \\
\text { KPRDSB }\end{array}$ & 7 of 9 & $\begin{array}{l}\text { Staff } \\
\text { Member }\end{array}$ & yes & yes & yes & $\begin{array}{l}\text { open- } \\
\text { ended }\end{array}$ \\
\hline $\begin{array}{l}\text { Keewatin } \\
\text { KPDSB }\end{array}$ & 4 of 4 & staff member & yes & yes & yes & $\begin{array}{l}\text { open- } \\
\text { ended }\end{array}$ \\
\hline $\begin{array}{l}\text { Lambton } \\
\text { LKDSB }\end{array}$ & 4 of 4 & open-ended & yes & yes & yes & no \\
\hline
\end{tabular}




\begin{tabular}{|c|c|c|c|c|c|c|}
\hline $\begin{array}{l}\text { Limestone } \\
\text { LDSB }\end{array}$ & 4 of 4 & $\begin{array}{l}\text { "Staff } \\
\text { Member" }\end{array}$ & no & $\begin{array}{l}\text { yes - only in } \\
\text { review } \\
\text { section }\end{array}$ & no & $\begin{array}{l}\text { open- } \\
\text { ended }\end{array}$ \\
\hline $\begin{array}{l}\text { Near North } \\
\text { NNDSB }\end{array}$ & 4 of 5 & $\begin{array}{l}\text { "Staff } \\
\text { Member" }\end{array}$ & yes & yes & yes & yes \\
\hline $\begin{array}{l}\text { Ottawa- } \\
\text { Carleton } \\
\text { OCDSB }\end{array}$ & 5 of 7 & $\begin{array}{l}\text { "Staff } \\
\text { Member" }\end{array}$ & yes & yes & yes & yes \\
\hline $\begin{array}{l}\text { Rainbow } \\
\text { RDSB }\end{array}$ & 6 of 6 & open-ended & yes & yes & yes & yes \\
\hline $\begin{array}{l}\text { Rainy River } \\
\text { RRDSB }\end{array}$ & $\mathrm{n} / \mathrm{a}$ & open-ended & no & no & no & no \\
\hline $\begin{array}{l}\text { Renfrew } \\
\text { RCDSB }\end{array}$ & 5 of 6 & $\begin{array}{l}\text { IEP } \\
\text { Development } \\
\text { Team } \\
\text { (member, } \\
\text { position) }\end{array}$ & yes & yes & yes & $\begin{array}{l}\text { open- } \\
\text { ended }\end{array}$ \\
\hline $\begin{array}{l}\text { Toronto } \\
\text { TDSB }\end{array}$ & 5 & $\begin{array}{l}\text { "TDSB } \\
\text { Team } \\
\text { Members" }\end{array}$ & yes & yes & yes & yes \\
\hline $\begin{array}{l}\text { Trillium } \\
\text { Lakelands } \\
\text { TLDSB }\end{array}$ & 6 of 6 & $\begin{array}{l}\text { Staff } \\
\text { Member }\end{array}$ & yes & yes & yes & no \\
\hline
\end{tabular}




\begin{tabular}{|c|c|c|c|c|c|c|}
\hline $\begin{array}{l}\text { Waterloo } \\
\text { WRDSB }\end{array}$ & 10 & $\begin{array}{l}\text { IEP } \\
\text { Development } \\
\text { Team }\end{array}$ & yes & yes & yes & $\begin{array}{l}\text { open- } \\
\text { ended }\end{array}$ \\
\hline $\begin{array}{l}\text { York } \\
\text { YRDSB }\end{array}$ & 1 & not listed & yes & yes & yes & $\begin{array}{l}\text { no parent } \\
\text { section, } \\
\text { can only } \\
\text { fit in } \\
\text { "other" } \\
\text { section }\end{array}$ \\
\hline $\begin{array}{l}\text { Algonquin } \\
\text { Lakeshore } \\
\text { Catholic } \\
\text { ALCDSB }\end{array}$ & $\mathrm{n} / \mathrm{a}$ & Names-Titles & no & no & no & $\begin{array}{l}\text { open- } \\
\text { ended }\end{array}$ \\
\hline $\begin{array}{l}\text { Bruce-Grey } \\
\text { Catholic }\end{array}$ & 6 of 6 & $\begin{array}{l}\text { Staff } \\
\text { Member }\end{array}$ & yes & yes & yes & $\begin{array}{l}\text { check } \\
\text { boxes }\end{array}$ \\
\hline $\begin{array}{l}\text { Halton } \\
\text { Catholic }\end{array}$ & $\mathrm{n} / \mathrm{a}$ & open-ended & no & yes & no & $\begin{array}{l}\text { open- } \\
\text { ended }\end{array}$ \\
\hline $\begin{array}{l}\text { Hamilton- } \\
\text { Wentworth } \\
\text { Catholic }\end{array}$ & 4 of 4 & $\begin{array}{l}\text { Staff } \\
\text { Member }\end{array}$ & yes & yes & yes & $\begin{array}{l}\text { open- } \\
\text { ended }\end{array}$ \\
\hline $\begin{array}{l}\text { Huron- } \\
\text { Superior } \\
\text { Catholic } \\
\end{array}$ & $\mathrm{n} / \mathrm{a}$ & not listed & no & no & no & $\begin{array}{l}\text { open- } \\
\text { ended }\end{array}$ \\
\hline $\begin{array}{l}\text { Kenora } \\
\text { Catholic }\end{array}$ & 7 of 7 & $\begin{array}{l}\text { Staff } \\
\text { Member }\end{array}$ & yes & yes & yes & $\begin{array}{l}\text { open- } \\
\text { ended }\end{array}$ \\
\hline $\begin{array}{l}\text { London } \\
\text { District } \\
\text { Catholic }\end{array}$ & 7 of 7 & $\begin{array}{l}\text { Staff } \\
\text { Member }\end{array}$ & no & yes & no & no \\
\hline $\begin{array}{l}\text { Niagara } \\
\text { Catholic }\end{array}$ & $\mathrm{n} / \mathrm{a}$ & $\begin{array}{l}\text { teacher/in } \\
\text { consultation } \\
\text { with }\end{array}$ & no & yes & no & $\begin{array}{l}\text { open- } \\
\text { ended }\end{array}$ \\
\hline $\begin{array}{l}\text { Northeastern } \\
\text { Catholic }\end{array}$ & 3 of 3 & open-ended & yes & yes & yes & no \\
\hline
\end{tabular}




\begin{tabular}{|c|c|c|c|c|c|c|}
\hline $\begin{array}{l}\text { Northwest } \\
\text { Catholic }\end{array}$ & 3 of 3 & $\begin{array}{l}\text { Staff } \\
\text { Member }\end{array}$ & yes & yes & yes & $\begin{array}{l}\text { check } \\
\text { boxes }\end{array}$ \\
\hline $\begin{array}{l}\text { Ottawa } \\
\text { Catholic } \\
\text { Elementary }\end{array}$ & 4 of 6 & $\begin{array}{l}\text { Staff } \\
\text { Member }\end{array}$ & yes & yes & yes & $\begin{array}{l}\text { check } \\
\text { boxes }\end{array}$ \\
\hline $\begin{array}{l}\text { Ottawa } \\
\text { Catholic } \\
\text { Secondary }\end{array}$ & 4 of 6 & $\begin{array}{l}\text { Staff } \\
\text { Member }\end{array}$ & yes & yes & yes & $\begin{array}{l}\text { check } \\
\text { boxes }\end{array}$ \\
\hline $\begin{array}{l}\text { Simcoe } \\
\text { Muskoka } \\
\text { Catholic } \\
\end{array}$ & 5 of 5 & $\begin{array}{l}\text { IEP Team } \\
\text { Members }\end{array}$ & yes & yes & yes & $\begin{array}{l}\text { check } \\
\text { boxes }\end{array}$ \\
\hline $\begin{array}{l}\text { St. Clair } \\
\text { Catholic }\end{array}$ & $\mathrm{n} / \mathrm{a}$ & open-ended & no & yes & no & $\begin{array}{l}\text { open- } \\
\text { ended }\end{array}$ \\
\hline $\begin{array}{l}\text { Sudbury } \\
\text { Catholic }\end{array}$ & 3 of 3 & $\begin{array}{l}\text { Staff } \\
\text { Member }\end{array}$ & yes & yes & yes & $\begin{array}{l}\text { check } \\
\text { boxes }\end{array}$ \\
\hline $\begin{array}{l}\text { Thunder Bay } \\
\text { Catholic }\end{array}$ & 5 of 5 & $\begin{array}{l}\text { Staff } \\
\text { Member }\end{array}$ & yes & yes & yes & $\begin{array}{l}\text { open- } \\
\text { ended }\end{array}$ \\
\hline $\begin{array}{l}\text { Waterloo } \\
\text { Catholic }\end{array}$ & 7 of 7 & $\begin{array}{l}\text { Staff } \\
\text { Member }\end{array}$ & yes & yes & yes & $\mathrm{n} / \mathrm{a}$ \\
\hline $\begin{array}{l}\text { York } \\
\text { Catholic }\end{array}$ & $\mathrm{n} / \mathrm{a}$ & $\begin{array}{l}\text { IEP } \\
\text { Development } \\
\text { Team }\end{array}$ & no & yes & no & $\begin{array}{l}\text { open- } \\
\text { ended }\end{array}$ \\
\hline
\end{tabular}




\begin{tabular}{|c|c|c|c|c|c|c|}
\hline $\begin{array}{l}\text { Schoolboar } \\
\text { d }\end{array}$ & $\begin{array}{l}\text { Assessmen } \\
\text { t Data }\end{array}$ & $\begin{array}{l}\text { Variatio } \\
\mathrm{n} \text { in } \\
\text { Font } \\
\text { Sizes }\end{array}$ & $\begin{array}{l}\text { Use of } \\
\text { Heading } \\
\text { s }\end{array}$ & $\begin{array}{l}\text { Parent } \\
\text { Assessme } \\
\text { nt section }\end{array}$ & $\begin{array}{l}\text { Proximity/relation } \\
\text { of Parent } \\
\text { involvement check } \\
\text { box to other } \\
\text { elements on page }\end{array}$ & $\begin{array}{l}\text { Strength of } \\
\text { Relationship } \\
\text { btwn Parent } \\
\text { input \& IEP } \\
\text { results } \\
\text { (Gestalt) }\end{array}$ \\
\hline $\begin{array}{l}\text { Avon } \\
\text { Maitland }\end{array}$ & "relevant" & yes & yes & no & $\mathrm{n} / \mathrm{a}$ & $\begin{array}{l}\text { no parent } \\
\text { input/commen } \\
\text { ts }\end{array}$ \\
\hline $\begin{array}{l}\text { Bluewater } \\
\text { BWDSB }\end{array}$ & open-ended & yes & yes & no & $\mathrm{n} / \mathrm{a}$ & $\begin{array}{l}\text { no parent } \\
\text { input/commen } \\
\text { ts }\end{array}$ \\
\hline $\begin{array}{l}\text { Niagara } \\
\text { DSBN }\end{array}$ & open-ended & yes & yes & no & $\begin{array}{l}\text { page } 5 \text {; after IEP } \\
\text { results }\end{array}$ & $\begin{array}{l}\text { weak; at end } \\
\text { of document, } \\
\text { on separate } \\
\text { page }\end{array}$ \\
\hline $\begin{array}{l}\text { Ontario } \\
\text { NorthEast }\end{array}$ & open-ended & yes & yes & no & $\mathrm{n} / \mathrm{a}$ & $\begin{array}{l}\text { no parent } \\
\text { input/commen } \\
\text { ts }\end{array}$ \\
\hline Durham & $\begin{array}{l}\text { education } \\
\text { and clinical }\end{array}$ & yes & yes & no & $\begin{array}{l}\text { page } 5 \text {; closest to } \\
\text { consultation log, last } \\
\text { page }\end{array}$ & $\begin{array}{l}\text { weak; on } \\
\text { separate } \\
\text { pages, at end } \\
\text { of document }\end{array}$ \\
\hline $\begin{array}{l}\text { Halton } \\
\text { HDSB }\end{array}$ & $\begin{array}{l}\text { education } \\
\text { and clinical }\end{array}$ & yes & yes & no & $\mathrm{n} / \mathrm{a}$ & $\begin{array}{l}\text { no parent } \\
\text { input/commen } \\
\text { ts }\end{array}$ \\
\hline $\begin{array}{l}\text { Kawartha } \\
\text { KPRDSB }\end{array}$ & open-ended & yes & yes & no & $\begin{array}{l}\text { page } 7 \text {; after special } \\
\text { educatoin plan }\end{array}$ & $\begin{array}{l}\text { weak; on } \\
\text { separate } \\
\text { pages, at end } \\
\text { of document }\end{array}$ \\
\hline $\begin{array}{l}\text { Keewatin } \\
\text { KPDSB }\end{array}$ & open-ended & yes & yes & no & $\begin{array}{l}\text { page } 4 \text {; after special } \\
\text { education program }\end{array}$ & $\begin{array}{l}\text { weak; on } \\
\text { separate } \\
\text { pages, at end } \\
\text { of document }\end{array}$ \\
\hline $\begin{array}{l}\text { Lambton } \\
\text { LKDSB }\end{array}$ & open-ended & yes & yes & no & $\begin{array}{l}\text { page } 4 \text {; after special } \\
\text { education program }\end{array}$ & $\begin{array}{l}\text { weak; on } \\
\text { separate } \\
\text { pages, at end } \\
\text { of document }\end{array}$ \\
\hline
\end{tabular}




\begin{tabular}{|c|c|c|c|c|c|c|}
\hline $\begin{array}{l}\text { Limestone } \\
\text { LDSB }\end{array}$ & $\begin{array}{l}\text { Informatio } \\
\mathrm{n} \text { Source - } \\
\text { targeted to } \\
\text { health } \\
\text { assessment } \\
\text { s }\end{array}$ & yes & yes & no & $\begin{array}{l}\text { page } 4 \text {; after special } \\
\text { education program }\end{array}$ & $\begin{array}{l}\text { weak; on } \\
\text { separate } \\
\text { pages, at end } \\
\text { of document }\end{array}$ \\
\hline $\begin{array}{l}\text { Near North } \\
\text { NNDSB }\end{array}$ & $\begin{array}{l}\text { Informatio } \\
\mathrm{n} \text { Source - } \\
\text { targeted to } \\
\text { health } \\
\text { assessment } \\
\text { s }\end{array}$ & yes & yes & no & $\begin{array}{l}\text { page } 4 \text {; before special } \\
\text { education program }\end{array}$ & $\begin{array}{l}\text { weak; on } \\
\text { separate pages }\end{array}$ \\
\hline $\begin{array}{l}\text { Ottawa- } \\
\text { Carleton } \\
\text { OCDSB }\end{array}$ & $\begin{array}{l}\text { "Informatio } \\
\text { n Source" - } \\
\text { health } \\
\text { professiona } \\
1 \text { oriented }\end{array}$ & yes & yes & no & $\begin{array}{l}\text { page } 5 \text {; after IEP } \\
\text { results }\end{array}$ & $\begin{array}{l}\text { weak; parent } \\
\text { comments is } \\
\text { after IEP } \\
\text { results and } \\
\text { different page }\end{array}$ \\
\hline $\begin{array}{l}\text { Rainbow } \\
\text { RDSB }\end{array}$ & $\begin{array}{l}\text { Summary } \\
\text { of } \\
\text { information } \\
\text { sources } \\
\end{array}$ & yes & yes & no & $\begin{array}{l}\text { page } 6 \text {; very last page } \\
\text { at bottom }\end{array}$ & $\begin{array}{l}\text { no parent } \\
\text { input/commen } \\
\text { ts }\end{array}$ \\
\hline $\begin{array}{l}\text { Rainy River } \\
\text { RRDSB }\end{array}$ & open-ended & yes & yes & no & $\mathrm{n} / \mathrm{a}$ & $\begin{array}{l}\text { no parent } \\
\text { input/commen } \\
\text { ts }\end{array}$ \\
\hline $\begin{array}{l}\text { Renfrew } \\
\text { RCDSB }\end{array}$ & $\begin{array}{l}\text { Educationa } \\
1\end{array}$ & yes & yes & no & $\begin{array}{l}\text { page } 5 \text {; after IEP } \\
\text { results }\end{array}$ & $\begin{array}{l}\text { weak; parent } \\
\text { comments are } \\
\text { on last page, } \\
\text { very last item, } \\
\text { after IEP is } \\
\text { developed. }\end{array}$ \\
\hline $\begin{array}{l}\text { Toronto } \\
\text { TDSB }\end{array}$ & $\begin{array}{l}\text { "Informatio } \\
\text { n Source" - } \\
\text { open- } \\
\text { ended, } \\
\text { parents can } \\
\text { contribute }\end{array}$ & yes & yes & no & $\begin{array}{l}\text { page } 5 \text {; last page, } \\
\text { after IEP results }\end{array}$ & $\begin{array}{l}\text { weak; parent } \\
\text { comments are } \\
\text { on last page, } \\
\text { very last item, } \\
\text { after IEP is } \\
\text { developed. }\end{array}$ \\
\hline $\begin{array}{l}\text { Trillium } \\
\text { Lakelands } \\
\text { TLDSB }\end{array}$ & $\begin{array}{l}\text { education } \\
\text { and clinical }\end{array}$ & yes & yes & no & $\begin{array}{l}\text { page } 6 \text {; last page after } \\
\text { IEP results }\end{array}$ & $\begin{array}{l}\text { weak; parent } \\
\text { comments at } \\
\text { end of } \\
\text { document }\end{array}$ \\
\hline
\end{tabular}




\begin{tabular}{|c|c|c|c|c|c|c|}
\hline $\begin{array}{l}\text { Waterloo } \\
\text { WRDSB }\end{array}$ & $\begin{array}{l}\text { clinical vs. } \\
\text { nonclinical }\end{array}$ & yes & yes & no & $\begin{array}{l}\text { page 10; after IEP } \\
\text { results }\end{array}$ & $\begin{array}{l}\text { weak; parent } \\
\text { comments is } \\
\text { on last page, } \\
\text { after IEP is } \\
\text { developed. }\end{array}$ \\
\hline $\begin{array}{l}\text { York } \\
\text { YRDSB }\end{array}$ & & yes & yes & no & $\begin{array}{l}\text { before IEP } \\
\text { results/accommodatio } \\
\text { ns }\end{array}$ & $\begin{array}{l}\text { weak: no } \\
\text { parent input }\end{array}$ \\
\hline $\begin{array}{l}\text { Algonquin } \\
\text { Lakeshore } \\
\text { Catholic } \\
\text { ALCDSB } \\
\end{array}$ & open-ended & yes & yes & no & $\mathrm{n} / \mathrm{a}$ & $\begin{array}{l}\text { no parent } \\
\text { input/commen } \\
\text { ts }\end{array}$ \\
\hline $\begin{array}{l}\text { Bruce-Grey } \\
\text { Catholic }\end{array}$ & $\begin{array}{l}\text { Informatio } \\
\mathrm{n} \text { Source - } \\
\text { targeted to } \\
\text { healthcare }\end{array}$ & yes & yes & no & page 6 ; very last page & $\begin{array}{l}\text { weak; at end } \\
\text { of document, } \\
\text { on separate } \\
\text { page }\end{array}$ \\
\hline $\begin{array}{l}\text { Halton } \\
\text { Catholic }\end{array}$ & open-ended & yes & yes & no & $\mathrm{n} / \mathrm{a}$ & $\begin{array}{l}\text { no parent } \\
\text { input/commen } \\
\text { ts }\end{array}$ \\
\hline $\begin{array}{l}\text { Hamilton- } \\
\text { Wentworth } \\
\text { Catholic }\end{array}$ & open-ended & yes & yes & no & $\begin{array}{l}\text { page } 4 \text {; last page at } \\
\text { bottom }\end{array}$ & $\begin{array}{l}\text { weak; on } \\
\text { separate page } \\
\text { and very last } \\
\text { page of IEP } \\
\text { package }\end{array}$ \\
\hline $\begin{array}{l}\text { Huron- } \\
\text { Superior } \\
\text { Catholic } \\
\end{array}$ & open-ended & yes & yes & no & $\mathrm{n} / \mathrm{a}$ & $\begin{array}{l}\text { no parent } \\
\text { input/commen } \\
\text { ts }\end{array}$ \\
\hline $\begin{array}{l}\text { Kenora } \\
\text { Catholic }\end{array}$ & $\begin{array}{l}\text { Informatio } \\
\text { n Source - } \\
\text { targeted to } \\
\text { healthcare }\end{array}$ & yes & yes & no & $\begin{array}{l}\text { page } 7 \text {; after special } \\
\text { education plan }\end{array}$ & $\begin{array}{l}\text { weak; parent } \\
\text { comments on } \\
\text { separate page } \\
\text { at end of IEP }\end{array}$ \\
\hline $\begin{array}{l}\text { London } \\
\text { District } \\
\text { Catholic } \\
\end{array}$ & open-ended & yes & yes & no & $\mathrm{n} / \mathrm{a}$ & $\begin{array}{l}\text { no parent } \\
\text { input/commen } \\
\text { ts }\end{array}$ \\
\hline $\begin{array}{l}\text { Niagara } \\
\text { Catholic }\end{array}$ & $\begin{array}{l}\text { health } \\
\text { directed }\end{array}$ & yes & yes & no & $\mathrm{n} / \mathrm{a}$ & $\begin{array}{l}\text { no parent } \\
\text { input/commen } \\
\text { ts }\end{array}$ \\
\hline $\begin{array}{l}\text { Northeaster } \\
\text { n Catholic }\end{array}$ & open-ended & yes & yes & no & $\mathrm{n} / \mathrm{a}$ & $\begin{array}{l}\text { no parent } \\
\text { input/commen } \\
\text { ts }\end{array}$ \\
\hline
\end{tabular}




\begin{tabular}{|c|c|c|c|c|c|c|}
\hline $\begin{array}{l}\text { Northwest } \\
\text { Catholic }\end{array}$ & $\begin{array}{l}\text { health } \\
\text { directed }\end{array}$ & yes & yes & no & $\begin{array}{l}\text { page } 3 \text {; after special } \\
\text { education plan }\end{array}$ & $\begin{array}{l}\text { weak; on } \\
\text { separate page } \\
\text { at end of IEP }\end{array}$ \\
\hline $\begin{array}{l}\text { Ottawa } \\
\text { Catholic } \\
\text { Elementary } \\
\end{array}$ & $\begin{array}{l}\text { health } \\
\text { directed }\end{array}$ & yes & yes & no & $\begin{array}{l}\text { page } 4 \text {; on parent } \\
\text { consultation page }\end{array}$ & $\begin{array}{l}\text { weak; on } \\
\text { separate page }\end{array}$ \\
\hline $\begin{array}{l}\text { Ottawa } \\
\text { Catholic } \\
\text { Secondary }\end{array}$ & $\begin{array}{l}\text { health } \\
\text { directed }\end{array}$ & yes & yes & no & $\begin{array}{l}\text { page } 4 \text {; on parent } \\
\text { consultation page }\end{array}$ & $\begin{array}{l}\text { weak; on } \\
\text { separate page }\end{array}$ \\
\hline $\begin{array}{l}\text { Simcoe } \\
\text { Muskoka } \\
\text { Catholic } \\
\end{array}$ & open-ended & yes & yes & no & $\begin{array}{l}\text { page } 5 \text {; on } \\
\text { consultation page }\end{array}$ & $\begin{array}{l}\text { weak; on } \\
\text { separate page }\end{array}$ \\
\hline $\begin{array}{l}\text { St. Clair } \\
\text { Catholic }\end{array}$ & $\begin{array}{l}\text { health } \\
\text { directed }\end{array}$ & yes & yes & no & $\mathrm{n} / \mathrm{a}$ & $\begin{array}{l}\text { no parent } \\
\text { input/commen } \\
\text { ts }\end{array}$ \\
\hline $\begin{array}{l}\text { Sudbury } \\
\text { Catholic }\end{array}$ & $\begin{array}{l}\text { health } \\
\text { directed }\end{array}$ & yes & yes & no & $\begin{array}{l}\text { page } 3 \text {; after special } \\
\text { education plan }\end{array}$ & $\begin{array}{l}\text { weak; at end } \\
\text { of document, } \\
\text { on separate } \\
\text { page }\end{array}$ \\
\hline $\begin{array}{l}\text { Thunder } \\
\text { Bay } \\
\text { Catholic }\end{array}$ & check box & yes & yes & no & $\begin{array}{l}\text { page } 5 \text {; at end of IEP } \\
\text { document }\end{array}$ & $\begin{array}{l}\text { weak; at end } \\
\text { of document, } \\
\text { on separate } \\
\text { page }\end{array}$ \\
\hline $\begin{array}{l}\text { Waterloo } \\
\text { Catholic }\end{array}$ & open-ended & yes & yes & no & $\begin{array}{l}\text { page } 7 \text {; at end of IEP } \\
\text { document }\end{array}$ & $\begin{array}{l}\text { weak; at end } \\
\text { of document, } \\
\text { on separate } \\
\text { page }\end{array}$ \\
\hline $\begin{array}{l}\text { York } \\
\text { Catholic }\end{array}$ & $\begin{array}{l}\text { health } \\
\text { directed }\end{array}$ & yes & yes & no & $\mathrm{n} / \mathrm{a}$ & $\begin{array}{l}\text { no parent } \\
\text { input/commen } \\
\text { ts }\end{array}$ \\
\hline
\end{tabular}

